\title{
THE LEGACY OF PSYCHIATRY AND PSYCHOLOGY IN ALCOHOLICS ANONYMOUS FELLOWSHIP PROGRAM
}

\section{DZIEDZICTWO PSYCHIATRII I PSYCHOLOGII W PROGRAMIE WSPÓLNOTY ANONIMOWYCH ALKOHOLIKÓW}

\author{
Bohdan Tadeusz Woronowicz \\ Akmed, Consultation Centre, Warsaw, Poland \\ Akmed, Centrum Konsultacyjne, Warszawa, Polska
}

Alcohol Drug Addict 2020; 33 (2): 161-198 DOI: https://doi.org/10.5114/ain.2020.98880

\begin{abstract}
Alcoholics Anonymous (AA) is a form of mutual self-help for those with alcohol use disorders (AUD). The first AA group in Poland was established in 1974. Today, 2800 AA groups meet throughout Poland.

The goal of this article is to present AA Fellowship as one of the forms of support for those with alcohol use disorders and to acquaint others with its history, program, and basic principles. The author also examines the role of physicians and psychologists as it has developed and presents the results of research both on the effectiveness of involvement in AA Fellowship and on professional therapy using the AA program in work within the Minnesota Model.
\end{abstract}

Keywords: Alcoholism, Alcoholics Anonymous, Minnesota Model, Dependency treatment, Twelve-Step program

\section{Streszczenie}

Wspólnota Anonimowych Alkoholików (AA) jest jedną $\mathrm{z}$ form samopomocy dla osób z zaburzeniami używania alkoholu (AUD). W Polsce pierwsza grupa AA powstała w 1974 r., a obecnie działa ok. 2800 takich grup.

Celem artykułu jest przedstawienie Wspólnoty AA jako jednej z form wspierania osób $\mathrm{z}$ zaburzeniami używania alkoholu, zapoznanie $\mathrm{z}$ jej historią, programem i podstawowymi założeniami, ukazanie roli lekarzy i psychologów w jej rozwoju oraz zaprezentowanie wyników badań nad skutecznością zarówno uczestnictwa we Wspólnocie, jak i w profesjonalnej terapii wykorzystującej doświadczenia i program Wspólnoty w ramach modelu Minnesota.

Słowa kluczowe: alkoholizm, Anonimowi Alkoholicy, model Minnesota, leczenie uzależnienia, program Dwunastu Kroków

Correspondence to/Adres do korespondencji: Bohdan Tadeusz Woronowicz, Akmed, Centrum Konsultacyjne, ul. Mokotowska 6a, 00-641 Warszawa, Polska, phone: +48 512344906, e-mail: bohdantw@gmail.com

Authors' contribution/Wkład pracy autorów:

No ghostwriting and guest authorship declared./Nie występują zjawiska ghostwriting i guest authorship.

Submitted/Otrzymano: 27.03.2020 • Accepted/Przyjęto do druku: 27.05.2020

(C) 2020 Institute of Psychiatry and Neurology. Production and hosting by Termedia sp. z o.o.

This is an open access article under the CC BY-NC-ND license (http://creativecommons.org/licenses/by-nc-nd/4.0/) 


\section{NOTE}

Bohdan Tadeusz Woronowicz, M.D., Ph.D., is a psychiatrist, specialist and supervisor of dependence psychotherapy. He managed the Alcoholism Treatment Department for 35 years and then the Dependence Therapy Centre at the Institute of Psychiatry and Neurology in Warsaw. He has accompanied the Alcoholics Anonymous Fellowship for over 40 years and supports it and uses the AA program in the treatment of his patients.

\section{NOTKA}

Dr n. med. Bohdan Tadeusz Woronowicz, psychiatra, specjalista i superwizor psychoterapii uzależnień, przez 35 lat kierował Oddziałem Odwykowym, a następnie Ośrodkiem Terapii Uzależnień w Instytucie Psychiatrii i Neurologii w Warszawie. Od ponad 40 lat towarzyszy Wspólnocie Anonimowych Alkoholików - wspiera ją i wykorzystuje jej program w leczeniu swoich pacjentów.

\section{- INTRODUCTION}

In the treatment of people with psychoactive substance use disorders, including alcohol, cooperation between professionals (i.e. doctors, psychologists and other therapists) and patient support systems is necessary. "The natural and most widespread human support systems are marriage, close family, relatives or a group of friends. Other examples may include religious groups, groups serving the needy, volunteer service groups and widespread self-help/mutual assistance groups" [1:279].

Self-help groups significantly support health care systems through the beneficial effects on their members' health, which enable them to:

- manage the injury resulting from the problem,

- accept the problem,

- develop skills to deal with the problem,

- find emotional relief thanks to emotional and community support and understanding,

- control one's own fate through mutual support and satisfying similar needs,

- deepen knowledge about a common problem and get help to better understand it,

- participate in common actions through contact with people who have the same problems, obtain a psychosocial substitute for what has been lost,

- awaken the therapeutic possibilities of its members by learning practical ways of dealing with the problem,

- create a new system of relationships and finding a new way of life, thus creating conditions for its normalization [1:279-280].

\section{WPROWADZENIE}

W leczeniu osób z zaburzeniami używania substancji psychoaktywnych, w tym alkoholu, konieczna jest współpraca między profesjonalistami (tj. lekarzami, psychologami i innymi terapeutami) a systemami oparcia pacjenta. „Naturalnymi i najbardziej rozpowszechnionymi systemami oparcia dla człowieka są: małżeństwo, bliska rodzina, krewni czy grupa przyjaciół. Innymi przykładami mogą być grupy religijne, grupy służące osobom cierpiącym, grupy służb ochotniczych oraz szeroko rozpowszechnione grupy samopomocy/wzajemnej pomocy" [1: 279].

Grupy samopomocy wspierają w istotnym stopniu systemy ochrony zdrowia przez korzystny wpływ na stan zdrowia swoich członków, którym umożliwiają:

- opanowanie urazu będącego skutkiem zaistniałego problemu,

- akceptację problemu,

- doskonalenie umiejętności radzenia sobie z problemem,

- rozładowanie emocji dzięki emocjonalnemu oraz społecznemu oparciu i zrozumieniu,

- zapanowanie nad losem dzięki wzajemnemu wspieraniu się i zaspokajaniu zbliżonych potrzeb,

- pogłębianie wiedzy o wspólnym problemie oraz uzyskanie pomocy w jego lepszym zrozumieniu,

- wspólne działania przez kontakt z osobami mającymi te same problemy, uzyskanie psychospołecznego substytutu tego, co się straciło,

- rozbudzenie terapeutycznych możliwości u swoich członków przez poznanie praktycznych sposobów radzenia sobie z problemem,

- stworzenie nowego układu stosunków i znalezienie nowego sposobu na życie, a więc stworzenie warunków do jego normalizacji [1:279-280]. 
As a result of the abovementioned possibilities, the negative effects of many psychosocial problems an individual faces are limited. Participants in self-help groups model their own experiences and supplement them with knowledge from outside, i.e. from professionals.

Giving help to others, treated as a service to the community, a good deed, or self-improvement, improves self-esteem and thus has a very positive effect on the helper's well-being. Many people thus avoid the degradation experienced by those who are only recipients of help.

Among self-help groups, those supporting people with alcohol problems and their relatives are particularly popular, i.e. the Fellowship of Alcoholics Anonymous (AA), Al-Anon and Alateen family groups and abstinence clubs. Their great usefulness in providing effective support to these people is indisputable.

The aim of the article is to present the Fellowship of Alcoholics Anonymous, one form of support for people with alcohol use disorders (AUD), its history and the fundamental assumptions of the program, the role of doctors and psychologists in its formation and development, as well as the research results, both on the effects of participation in the AA Fellowship and participation in professional therapy using the AA experience and its program.

\section{- THE DEVELOPMENT OF THE AA FELLOWSHIP ACROSS THE WORLD}

The Fellowship of Alcoholics Anonymous has existed since 1935, that is, since two "hopeless" alcoholics met and instead of parting after a dozen or so minutes, spent many hours talking. Both were surprised that during this and subsequent meetings they did not feel the need to drink alcohol. When they realized this, they started looking for other people with alcohol problems and began meeting with them. This first meeting took place in Akron (Ohio, USA) thanks to mutual friends from the Oxford Group. Its participants were stockbroker Bill W. (William Griffith Wilson, 1895-1971) and surgeon Dr. Bob (Robert Halbrook Smith, 1879-1950). Bill had done a lot of time in alcoholism treatment centers (for example, he was hospitalized four times from 1933-
Dzięki wymienionym wyżej możliwościom dochodzi do ograniczenia ujemnych skutków wielu problemów psychospołecznych napotykanych przez jednostkę. Uczestnicy grup samopomocy wzorują się na własnych doświadczeniach i uzupełniają je o wiedzę pochodzącą z zewnątrz, tzn. od profesjonalistów.

Udzielanie pomocy innym, traktowane jako służba na rzecz społeczności, dobry uczynek czy samodoskonalenie, poprawia samoocenę i tym samym wpływa bardzo korzystnie na samopoczucie pomagającego. Wiele osób unika dzięki temu degradacji, jakiej doświadczają ci, którzy są tylko biorcami pomocy.

Wśród grup samopomocowych szczególną popularnością cieszą się te wspierające osoby z problemem alkoholowym i ich bliskich, czyli Wspólnota Anonimowych Alkoholików (AA), grupy rodzinne Al-Anon i Alateen oraz kluby abstynenta. Ich duża przydatność w udzielaniu skutecznego wsparcia tym osobom jest bezdyskusyjna.

Celem artykułu jest zaprezentowanie jednej $\mathrm{z}$ form wsparcia dla osób z zaburzeniami używania alkoholu (AUD), jaką jest Wspólnota AA. Przedstawienie jej historii, podstawowych założeń, ukazanie roli lekarzy i psychologów w jej powstawaniu i rozwoju, a także przedstawienie wyników badań - zarówno nad efektami uczestnictwa we Wspólnocie AA, jak i udziałem w profesjonalnej terapii wykorzystującej doświadczenia i program Wspólnoty.

\section{- ROZWÓJ WSPÓLNOTY AA NA ŚWIECIE}

Wspólnota Anonimowych Alkoholików istnieje od 1935 r., tj. od czasu, kiedy spotkało się dwóch „beznadziejnych” alkoholików i zamiast rozstać się po kilkunastu minutach, spędziło na rozmowie wiele godzin. Obaj byli zdziwieni, że podczas tego i kolejnych spotkań nie odczuwali potrzeby picia alkoholu. Kiedy to sobie uświadomili, zaczęli szukać innych osób z problemami alkoholowymi i spotykać się z nimi. To pierwsze spotkanie doszło do skutku w miejscowości Akron (Ohio, USA) dzięki wspólnym znajomym z Grupy Oksfordzkiej. Jego uczestnikami byli makler giełdowy Bill W. (William Griffith Wilson, 1895-1971) i chirurg dr Bob (Robert Halbrook Smith, 1879-1950). Bill miał za sobą wiele pobytów w zakładach odwykowych (np. w latach 1933-1934 był hospitalizowany czterokrotnie), a dr Bob nie był już w stanie operować [1: 282]. 
1934), and Dr. Bob was no longer able to perform operations [1:282].

The beginning of the Alcoholics Anonymous movement, and of earlier "anti-alcohol" movements, can be associated with groups established in the United States that promoted temperance (in Moreau, New York, in 1803 and in Boston in 1813). In 1826, the American Society for the Promotion of Temperance was established, which promulgated moderate alcohol consumption [2]. In the next stage, attempts of self-organization of alcoholics took place, when in Baltimore six men abusing alcohol established in 1840 Washingtonian Temperance Society and proclaimed the idea of a path back to a dignified life [3]. Initially, the association consisted of alcoholics and later various social and political activists began to join. At the peak of its development, the Association had 300,000, possibly 600,000, members [4: 40-45, 5: 19]. Gradually, however, it began to deal with other important social issues, e.g. the abolition of slavery and politics. As a result, the original idea of supporting alcoholics collapsed after a few years.

At the turn of the nineteenth and twentieth centuries, a First Century Christian Fellowship was created thanks to the Lutheran pastor, Dr. Frank Buchman, whose purpose was to renew what constituted the essence of Christianity from the first century A.D., later called the Oxford Group [1: 281]. There were, among others, Four Absolutes principle, i.e. absolute honesty (in relation to oneself and others, in words, deeds and thoughts), absolute unselfishness, absolute purity (body, mind and intentions) and absolute love (to God and neighbor, and to oneself) [6: 108]. The idea soon reached the United States and the founders of the AA Fellowship met thanks to contacts with the Oxford Group.

In the Oxford Groups, particular attention was paid to the morality and renewal of "sinners", so it was expected that the alcoholics who joined them would "fall on their knees" as sinners and stand up converted and "clean". This approach did not suit Bill W. and some alcoholics. They felt that "too aggressive evangelization" would deter many people from joining the Fellowship. As a result, in 1937, 40 alcoholics separated from the groups, taking the name "anonymous handful of alcoholics", and in 1938, Alcoholics Anonymous [1: 282]. This resulted in a change of language. Instead of sin there
Początek Wspólnoty AA, a wcześniej ruchów „przeciwalkoholowych”, można łączyć z powstałymi w Stanach Zjednoczonych towarzystwami propagującymi wstrzemięźliwość (1803 r. w Moreau w stanie Nowy Jork i w 1813 r. w Bostonie). W 1826 r. powstało Amerykańskie Stowarzyszenie Popierania Trzeźwości, które propagowało umiarkowane spożywanie alkoholu [2]. Kolejnym etapem były próby samoorganizowania się alkoholików, kiedy w mieście Baltimore sześciu mężczyzn nadużywających alkoholu założyło w 1840 r. Stowarzyszenie Trzeźwości im. Jerzego Waszyngtona i głosiło ideę drogi powrotu do godnego życia [3]. Stowarzyszenie to początkowo gromadziło w swoich szeregach samych alkoholików, później zaczęli dołączać różni działacze społeczni i polityczni. W szczytowym okresie rozwoju Stowarzyszenie liczyło 300, a może nawet 600 tys. członków [4: 40-45, 5: 19]. Stopniowo zaczęło zajmować się jednak innymi ważnymi społecznie sprawami, np. zniesieniem niewolnictwa i polityką. Na skutek tego, pierwotna idea wspierania alkoholików po kilku latach upadła.

Na przełomie XIX i XX w. za sprawą luterańskiego pastora, dr. Franka Buchmana, powstała Chrześcijańska Wspólnota Pierwszego Wieku, której celem było odnowienie tego, co stanowiło istotę chrześcijaństwa z I w. n.e. Z tej Wspólnoty wyłoniła się później tzw. Grupa Oksfordzka [1: 281]. Obowiązywała w niej m.in. zasada czterech absolutów, tj. absolutnej uczciwości (w stosunku do siebie i innych, w słowach, czynach i myślach), absolutnego altruizmu (stałej gotowości do pomagania innym), absolutnej czystości (ciała, umysłu i zamierzeń) oraz absolutnej miłości (do Boga i do bliźniego, takiej jak do siebie samego) [6: 108]. Ta idea dotarła wkrótce do Stanów Zjednoczonych i dzięki kontaktom z Grupą Oksfordzką spotkali się założyciele Wspólnoty AA.

W grupach oksfordzkich przywiązywano szczególną wagę do moralności i odnowy "grzeszników", oczekiwano zatem, że alkoholicy, którzy do nich dołączyli, będą "padać na kolana” jako grzesznicy i wstawać jako osoby nawrócone i „czyste”. Takie podejście nie odpowiadało Billowi W. i części alkoholików. Uznali oni, że „zbyt agresywna ewangelizacja” odstręcza wiele osób od przyłączenia się do Wspólnoty. W efekcie, w 1937 r. grupa 40. alkoholików odłączyła się od grup oksfordzkich, przyjmując nazwę „bezimienna garstka alkoholików", a w 1938 r. - Anonimowi Alkoho- 
was a recognition of powerless over alcohol, instead of "only God" the notion of "Higher Power", internal development instead of religiousness and spiritual awakening instead of moral renewal. Alcoholism ceased to be considered in terms of sin and began to be seen as a type of health problem. Hence, doctors and psychologists later played an important role in the development of the Fellowship and the shaping of its recovery program and are often called its "spiritual fathers". At the same time, they saw the Fellowship as an ally in the treatment of alcoholism ${ }^{1}$, which was called a disease by Jellinek only in 1946 [7].

The creation of the Alcoholics Anonymous Fellowship took place shortly after the end of Prohibition in the United States (The Noble Experiment of Prohibition from 1920 to 1933). Its rise was favored by social expectations, including the attitude of the American Society of Prohibition. Prohibition was in fact unpopular, costly and caused a lot of damage (including an increase in crime: the rise of the "black market" and the mafia and a decrease in respect for the law). Hence, any other activities aimed at reducing the negative effects of excessive use of alcohol met with public approval.

The idea of Alcoholics Anonymous has found many allies, not only in the medical world, but also among scientific authorities. One of the people whose views help lay the foundations for the AA program was the Harvard University professor William James ${ }^{2}$, a precursor of both behaviorism and humanistic psychology, a professor of philosophy and psychologist of religion who attached great importance to experience, especially religious (mystical) experiences. "The greatest discovery of my time is the truth that man can change himself by changing his attitude to the world" [8] is his well-known saying. The other person who influenced the shaping of the AA program was Carl Gustav Jung, a Swiss psychologist and psychiatrist, the creator of depth psychology. His views influenced one of the founders of AA, Bill W. [9-11] when he developed the Twelve-Step program. The ideological assumptions of AA were also influenced by an American psychiatrist and psychoanalyst, Harry Stock Sullivan, who proposed the the-

\footnotetext{
1 I deliberately use the word "alcoholism" here to fit in with the language being used at that time.

${ }^{2} \mathrm{He}$ abandoned medicine to become later the "father of American psychology".
}

licy [1: 282]. Pociągnęło to za sobą zmianę języka i zamiast grzechu pojawiło się uznanie bezsilności wobec alkoholu, zamiast „jedynego Boga” pojęcie „Siły Wyższej”, rozwój wewnętrzny zamiast religijności oraz przemiana duchowa zamiast odnowy moralnej. Alkoholizm przestał być rozpatrywany w kategoriach grzechu, zaczęto natomiast dostrzegać w nim jeden z problemów zdrowotnych. Dlatego lekarze i psychologowie odegrali później istotną rolę $\mathrm{w}$ rozwoju Wspólnoty oraz kształtowaniu się jej programu zdrowienia i bywają nazywani jej „ojcami duchowymi”. Jednocześnie dość szybko zauważyli we Wspólnocie sprzymierzeńca w leczeniu alkoholizmu'1, który dopiero w 1946 r. nazwany został przez Jellinka chorobą [7].

Powstanie Wspólnoty AA nastąpiło wkrótce po zakończeniu okresu prohibicji w Stanach Zjednoczonych (lata 1920-1933). Jej powstaniu sprzyjały oczekiwania społeczne, $w$ tym stosunek społeczeństwa amerykańskiego do prohibicji. Prohibicja była bowiem niepopularna, kosztowna i przyniosła wiele szkód (m.in. wzrost przestępczości - powstanie „czarnego rynku” i mafii oraz spadek szacunku dla prawa). Stąd wszelkie inne działania mające na celu ograniczenie negatywnych skutków nadmiernego używania alkoholu spotykały się ze społeczną aprobatą.

Idea AA znalazła wielu sprzymierzeńców nie tylko w świecie medycznym, lecz także wśród autorytetów naukowych. Jedną z osób, której poglądy dały podwaliny programowi Wspólnoty, był profesor Uniwersytetu Harvarda - William James ${ }^{2}$, prekursor zarówno behawioryzmu, jak i psychologii humanistycznej, profesor filozofii oraz psycholog religii, przywiązujący dużą wagę do doświadczeń i przeżyć religijnych (mistycznych). Znane jest jego powiedzenie: „Największe odkrycie moich czasów to prawda, że człowiek może zmienić siebie, zmieniając swój stosunek do świata" [8]. Drugą osobą, która wpłynęła na kształtowanie się programu AA, był Carl Gustav Jung, szwajcarski psycholog i psychiatra, twórca psychologii głębi. Podczas opracowywania programu Dwunastu Kroków jego poglądy wziął pod uwagę jeden z założycieli AA - Bill W. [9-11]. Na założenia ideowe AA wywarł również wpływ amerykański psychiatra i psychoanalityk Harry Stock Sullivan, który postawił tezę, że „budowanie bezpieczeństwa nie

\footnotetext{
${ }^{1}$ Celowo używam tu słowa „alkoholizm”, aby być w zgodzie z obowiązującym wówczas nazewnictwem.

${ }^{2}$ Porzucił medycynę, aby stać się później „ojcem amerykańskiej psychologii”.
} 
sis that "building security is not done by avoiding threats but meeting them" [12: 521].

From the first days of its existence, the New York physician and neurologist William Silkworth provided special support to the emerging Fellowship of Alcoholics Anonymous. He was said to be "a little doctor who loved drunks". In the 1930s, he treated Bill W. and suggested that he read the works of William James, including "Religious Experiences", where one could read that the occurrence of "spiritual upheavals" were preceded by hard life experiences [13]. William Silkworth was the first doctor to be called a true friend of AA. In turn, the psychiatrist, Dr. Harry Tiebout, was the first in his department to separate places for the treatment of alcoholics, and in his work used the experience of AA and persuaded other doctors to use it as well. He met Bill W., treating him because of depression, and then became convinced of the AA program. In July 1939, he published his first AA article in the Lancet, "A New Approach to Psychotherapy in Chronic Alcoholism", and in the 1940s and 1950s in the Quarterly Journal of Studies on Alcohol he published several articles on the treatment of alcoholism and the role of AA in this treatment [14-17]. In 1957 he became a Class A (non-alcoholic) Trustee in the AA Fellowship 3 .

The important role of the AA Fellowship in the alcoholism recovery was drawn to the attention of many people who in the early years supported it very much, including clergy such as Frank Buchman (mentioned above); Dr. Samuel Shoemaker, a pastor in the Episcopal Church; the Jesuit priest Fr. Edward Dowling; and Sister Mary Ignatia from the Catholic order of the Sisters of Mercy of Saint Augustine. The Protestant clergyman Dr. Harry Emerson Fosdick, reviewer of the book "Alcoholics Anonymous" published in 1939 (colloquially called the "Big Book") ${ }^{4}$, wrote: "when an ex-alcoholic (...) talks to an active alcoholic, then the results can be extraordinary, and that's how they were in the lives of countless thou-

${ }^{3}$ I also had the honor of being the first Class A Trustee (a member of the Trusteeship Council - a non-alcoholic) in the Polish AA Fellowship and served for almost 10 years.

${ }^{4}$ The book has since been translated into 71 languages, it has large print and abridged versions and is available in Braille and on cassette, CD and DVD. In 2019, 40-millionth copy was printed. In 1973, the millionth copy was given to President Nixon. odbywa się przez unikanie zagrożeń, lecz wychodzenie im naprzeciw" [12: 521].

Szczególnego wsparcia powstającej Wspólnocie AA udzielał, od pierwszych dni jej istnienia, nowojorski lekarz-neurolog William Silkworth - mówiono o nim: „mały lekarz, który kochał pijaków". W latach 30. leczył Billa W. i podsunął mu wówczas prace Williama Jamesa, w tym „Doświadczenia religijne”, gdzie można było przeczytać, że trudne doświadczenia życiowe poprzedzają wystąpienie „wstrząsów duchowych” [13]. William Silkworth był pierwszym lekarzem, którego można nazwać prawdziwym przyjacielem AA. Z kolei lekarz-psychiatra, dr Harry Tiebout, jako pierwszy w prowadzonym przez siebie oddziale wydzielił miejsca do leczenia alkoholików, a w swojej pracy wykorzystywał doświadczenia AA i przekonywał do nich innych lekarzy. Z Billem W. zetknął się, lecząc go z powodu depresji, i wówczas przekonał się do Wspólnoty AA. W lipcu 1939 r. w czasopiśmie Lancet opublikował swój pierwszy artykuł na temat AA pt. „Nowe podejście do psychoterapii w przewlekłym alkoholizmie", a w latach 40 . i 50. w Quarterly Journal of Studies on Alcohol opublikował kilka artykułów dotyczących leczenia alkoholizmu i roli AA w tym leczeniu [14-17]. W $1957 \mathrm{r}$. został Powiernikiem klasy A (nie-alkoholikiem) we Wspólnocie $\mathrm{AA}^{3}$.

$\mathrm{Na}$ ważną rolę Wspólnoty AA w „wychodzeniu" $\mathrm{z}$ alkoholizmu zwracało uwagę wiele osób, które w pierwszych latach bardzo ją wspierały, w tym osoby duchowne, takie jak wspomniany już Frank Buchman, dr Samuel Shoemaker - pastor Kościoła Episkopalnego, ojciec Edward Dowling, jezuita, czy siostra Mary Ignatia z katolickiego zakonu Sióstr Miłosierdzia św. Augustyna. Protestancki duchowny, dr Harry Emerson Fosdick, recenzent wydanej w 1939 r. książki „Anonimowi Alkoholicy” (potocznie nazywanej „Wielką Księgą” - „Big Book”)", napisał: „gdy eksalkoholik (...) rozmawia $\mathrm{z}$ aktywnym alkoholikiem, wówczas wyniki potrafią być nadzwyczajne i takie właśnie były w życiu niezliczonych tysięcy ludzi” [18: 422].

${ }^{3}$ Ja także dostąpiłem zaszczytu bycia pierwszym Powiernikiem klasy A (członkiem Rady Powierniczej - nie-alkoholikiem) w polskiej Wspólnocie AA i pełniłem tę służbę przez prawie 10 lat.

${ }^{4} \mathrm{~W}$ międzyczasie książka została przetłumaczona na 71 języków, ma wersję $\mathrm{z}$ dużym drukiem, skróconą i w Braille'u oraz na kasecie, CD i DVD. W 2019 r. wydrukowano 40-milionowy egzemplarz. Milionowy egzemplarz przekazano w 1973 r. prezydentowi Nixonowi. 
sands of people" [18: 422]. In turn, Prof. Foster Kennedy (President of the American Neurological Society since 1940) stated "I have no doubt that a man who has cured himself of his attraction to alcohol is far more powerful in treating alcoholism than a doctor who has never been marked by this curse" [18: 417].

The first AA group at a hospital was established in December 1939 at Rockland State Hospital in New York state ${ }^{5}$. Another historical event was the article by Jack Alexander "Alcoholics Anonymous: Freed Slaves of Drink, Now They Free Others", published in 1941 in the Saturday Evening Post [19]. Thousands of letters and orders for the book Alcoholics Anonymous followed this article, and the AA Fellowship began to grow rapidly [20].

It is worth mentioning here that a similar role played in Poland Wiktor Osiatyński's article "Sin or Disease", published in Polityka in December 1985, and later published in 1992 by the Institute of Psychiatry and Neurology as the book of the same title ${ }^{6}$. As a result of these publications, many people decided to contact a therapeutic facility or join AA.

The acceptance of the AA Fellowship as a new opportunity in the treatment of alcoholics by the American Psychiatric Association in 1945, resulting from Dr. Tiebout's recommendation, can also be considered historic. Three years earlier, in 1942, the Fellowship made it through the gates of the San Quentin prison in California, where the first AA prison group was formed.

Another important event took place in 1951, when Alcoholics Anonymous received the Lasker Award (called the "American Nobel") from the American Public Health Association, thanks to the recommendation of the 12,000 doctor-members of this Association. The award was granted to Alcoholics Anonymous "in recognition of its unique and highly successful approach to alcoholism (...) that age-old public health and social problem. In emphasizing alcoholism as an illness, the social stigma associated with this condition

\footnotetext{
${ }^{5}$ In Poland, the first AA group in the hospital ward was established in 1980 at the Institute of Psychiatry and Neurology in Warsaw.

${ }^{6}$ At that time Wiktor Osiatyński was in the United States so I passed this article on to the editor-in-chief of Polityka, Daniel Passent on his behalf. In 2009, the article "Sin or Disease" was published by the BSK AA Foundation in the publication Zdrój.
}

Z kolei prof. Foster Kennedy (prezes Amerykańskiego Towarzystwa Neurologicznego od 1940 r.) stwierdził: „Nie mam żadnych wątpliwości, że człowiek, który sam siebie wyleczył z pociągu do alkoholu, jest znacznie większą potęgą w leczeniu alkoholizmu niż lekarz, który nigdy nie był naznaczony tym przekleństwem" [18: 417].

Pierwsza grupa AA na terenie szpitala powstała w grudniu 1939 r. w Rockland State Hospital w stanie Nowy Jork ${ }^{5}$. Kolejnym historycznym wydarzeniem był artykuł Jacka Alexandra pt. „Anonimowi Alkoholicy. Niewolnicy alkoholu uwolnieni, teraz uwalniają innych", zamieszczony w 1941 r. w Saturday Evening Post [19]. Po tym artykule napłynęło tysiące listów i zamówień na książkę „Anonimowi Alkoholicy", a Wspólnota zaczęła gwałtownie się rozrastać [20].

W tym miejscu warto wspomnieć, że podobną rolę odegrał w Polsce artykuł Wiktora Osiatyńskiego pt. „Grzech czy choroba”, zamieszczony w Polityce w grudniu 1985 r., a później wydany w 1992 r. przez Instytut Psychiatrii i Neurologii w książce pod tym samym tytułem ${ }^{6}$. Dzięki tym publikacjom wiele osób zdecydowało się nawiązać kontakt z placówką terapeutyczną lub przystąpić do AA.

Za historyczny można uznać również moment zaakceptowania w 1945 r. przez Amerykańskie Towarzystwo Psychiatryczne, dzięki rekomendacji dr. Tiebout, Wspólnoty AA jako nowej możliwości do wykorzystania w leczeniu alkoholików. Trzy lata wcześniej, w 1942 r., Wspólnota przekroczyła bramy więzienia w San Quentin w Kalifornii, gdzie powstała pierwsza grupa AA.

Kolejne ważne wydarzenie miało miejsce w 1951 r., kiedy Wspólnota AA otrzymała od Amerykańskiego Towarzystwa Zdrowia Publicznego, dzięki rekomendacji 12 tys. lekarzy-członków tego towarzystwa, Nagrodę Laskerów (nazywaną amerykańskim Noblem). Nagrodę przyznano „w uznaniu unikalnego i wybitnie skutecznego podejścia do alkoholizmu (...) odwiecznego problemu społecznego. Potwierdzając, że alkoholizm jest chorobą, AA pomaga jednocześnie zmyć przypisywane temu stanowi piętno społeczne" [21]. W 1956 r.

\footnotetext{
${ }^{5}$ W Polsce pierwsza grupa AA na terenie oddziału szpitalnego powstała w 1980 r. w Instytucie Psychiatrii i Neurologii w Warszawie.

${ }^{6} \mathrm{~W}$ tym czasie Wiktor Osiatyński przebywał w Stanach Zjednoczonych. W Jego imieniu przekazałem ten artykuł ówczesnemu redaktorowi naczelnemu Polityki - Danielowi Passentowi. W 2009 r. artykuł "Grzech czy choroba” wydany został przez Fundację BSK AA w Biblioteczce Zdroju.
} 
is being blotted out" [21]. In 1956, the American Medical Association recognized alcoholism as a disease, largely due to contacts with representatives of the AA Fellowship. The published resolution states that "hospitals should consider admission of patients diagnosed with alcoholism based on the specific patient's condition and not on general opposition to all such patients" [22]. Soon, a similar approach to the treatment for alcoholism appeared in Europe [23].

Currently, the American Psychological Association and the American Psychiatric Association recommend directing patients treated for addiction to self-help groups [24, 25]. Groups using a Twelve-Step program are treated as an important element of the care system for patients with psychoactive substance use disorders [26].

In recent years, Prof. George Vaillant has played an extremely important role in popularizing the idea of Alcoholics Anonymous Fellowship. He is a psychiatrist and psychoanalyst, a professor at Harvard University, author of many studies and publications on psychology, psychiatry and alcoholism, including studies on AA, and was honored in 1991 with the Jellinek Memorial Award7. He supported and strongly recommended AA as a way of coping with alcohol dependence and pointed out that "AA doesn't stop working even when the patient leaves the clinic". In 1998, he even became a Class A Trustee of the AA General Service Board [27].

Random surveys of members of AA Fellowship conducted since 1968 in the United States and Canada, also include information about the Fellowship and its relationship with health care. According to research from 2014 in which 6,000 members participated, $59 \%$ of respondents received some form of therapy in connection with their drinking, and $57 \%$ were referred to AA by health care workers [28]. In turn, Polish research showed that $76.9 \%$ of AA members surveyed participated in therapy in addiction treatment centers before joining AA [29]. These facts are an example of mutual cooperation in helping alcohol dependent persons.

\footnotetext{
${ }^{7}$ Jellinek Memorial Award - established in 1965 is an award commemorating Dr. Elvin Morton Jellinek's great contribution to the field of alcohol research. It is awarded annually to researchers who have made an outstanding contribution to the development of knowledge on the topic of alcohol.
}

Amerykańskie Towarzystwo Medyczne uznało alkoholizm za chorobę, w dużym stopniu dzięki kontaktom z przedstawicielami Wspólnoty AA. W opublikowanej rezolucji stwierdzono, że: „należy wezwać szpitale do rozważenia przyjmowania pacjentów $\mathrm{z}$ rozpoznaniem alkoholizmu, opierając się na stanie konkretnego pacjenta, a nie na ogólnym sprzeciwie wobec wszystkich takich pacjentów" [22]. Wkrótce podobne podejście do leczenia alkoholizmu pojawiło się w Europie [23].

Obecnie Amerykańskie Towarzystwo Psychologiczne i Amerykańskie Towarzystwo Psychiatryczne zalecają kierowanie pacjentów leczonych $\mathrm{z}$ powodu uzależnień do grup samopomocowych $[24,25]$. Grupy posługujące się programem Dwunastu Kroków są traktowane jako ważny element systemu opieki nad pacjentami z zaburzeniami używania substancji psychoaktywnych [26].

$\mathrm{W}$ ostatnich latach niezwykle ważną rolę w popularyzacji idei Wspólnoty AA odegrał prof. George Vaillant, psychiatra i psychoanalityk, profesor Uniwersytetu Harvarda, autor wielu badań i publikacji dotyczących psychologii, psychiatrii i alkoholizmu, w tym również badań na temat AA, uhonorowany w 1991 r. Jellinek Memorial Award ${ }^{7}$. Wspierał i gorąco polecał Wspólnotę AA jako sposób na radzenie sobie $\mathrm{z}$ uzależnieniem od alkoholu i zwracał uwagę na to, że: „AA nie przestaje działać nawet wtedy, kiedy pacjent opuści klinikę”. W 1998 r. został nawet Powiernikiem klasy A we Wspólnocie AA [27].

Prowadzone od 1968 r. losowe badania ankietowe członków Wspólnoty AA w Stanach Zjednoczonych i Kanadzie uwzględniają także informacje na temat Wspólnoty i jej związków z lecznictwem. Jak wynikało z badań z 2014 r., z udziałem 6 tys. członków, 59\% ankietowanych uczestniczyło w jakiejś formie terapii w związku ze swoim piciem, a 57\% zostało skierowanych do AA przez pracowników ochrony zdrowia [28]. Z kolei polskie badania wykazały, że 76,9\% ankietowanych członków AA przed przystąpieniem do AA brało udział $\mathrm{w}$ terapii w placówkach lecznictwa odwykowego [29]. Te fakty są przykładem wzajemnego uzupełniania się w niesieniu pomocy osobom uzależnionym od alkoholu.

\footnotetext{
${ }^{7}$ Jellinek Memorial Award - ustanowiona w 1965 r. nagroda upamiętniająca wielki wkład dr. Elvina Mortona Jellinka w dziedzinę badań nad alkoholem. Jest corocznie przyznawana badaczom, którzy wnieśli wybitny wkład w rozwój wiedzy na temat alkoholu.
} 
The AA Fellowship in the world currently has over 2 million members and over 120,000 groups (according to the General Service Office, in 2018 there were 2,130,419 members and 125,352 AA groups) [30]. It is worth mentioning that there are also separate AA groups in the Fellowship for special populations (broader description on page 170) [31].

The principles of Alcoholics Anonymous have been adopted by many other self-help groups in the world, for example Narcotics Anonymous which started in 1953; Gamblers Anonymous (1957); Overeaters Anonymous (1960); Debtors Anonymous (1968); Pills Anonymous (1975); Workaholics Anonymous (1983); Nicotine Anonymous (1985); Cancer Anonymous (1987) and Diabetics Anonymous (1990). There are also other self-help groups for people who suffer from phobias (Phobics Anonymous), depression (Depressed Anonymous), schizophrenia (Schizophrenics Anonymous) and also those suffering from dual diagnosis disorder (Dual Disorders Anonymous) [1:293].

\section{- THE RECOVERY PROGRAM PROPOSED BY AA AND the Minnesota Model}

The program of recovery proposed by Alcoholics Anonymous Fellowship is laid out in Twelve Steps. The Twelve Traditions serve to preserve the unity of the Fellowship. The basic information regarding the Fellowship is in the Preamble:

"Alcoholics Anonymous is a fellowship of men and women who share their experience, strength and hope with each other that they may solve their common problem and help others to recover from alcoholism. The only requirement for membership is a desire to stop drinking. There are no dues or fees for A.A. membership; we are self-supporting through our own contributions. A.A. is not allied with any sect, denomination, politics, organization or institution; does not wish to engage in any controversy, neither endorses nor opposes any causes. Our primary purpose is to stay sober and help other alcoholics to achieve sobriety". One can also read that "The principles we have set down are guides to progress" [21: 50-51].

A closer and more detailed look at the Twelve-Step program, knowledge of the literature associated with it, and especially the personal partic-
Obecnie Wspólnota AA na świecie liczy ponad 2 mln członków, którzy spotykają się w ponad 120 tys. grup (wg General Service Office w 2018 r. było 2130419 członków oraz 125352 grupy AA) [30]. Warto wspomnieć, że we Wspólnocie funkcjonują również oddzielne grupy AA dla specjalnych populacji (szersze omówienie na str. 170) [31].

Zasady AA zostały zaadaptowane przez wiele innych grup samopomocowych. Na świecie spotykają się, że wymienię dla przykładu tylko kilka z nich, grupy Anonimowych Narkomanów od 1953 r., Anonimowych Hazardzistów (1957 r.), Anonimowych Żarłoków (1960 r.), Anonimowych Dłużników (1968 r.), Anonimowych Lekomanów (1975 r.), Anonimowych Pracoholików (1983 r.), Anonimowych Nikotynistów (1985 r.), Anonimowych Chorych na Raka (1987 r.) czy Anonimowych Chorych na Cukrzycę (1990 r.). Istnieją również grupy samopomocowe dla osób cierpiących na fobie, dla chorych na depresję, schizofrenię, a także dla osób z tzw. podwójną diagnozą [1:293].

\section{- PROgRAM ZDROWIENIA PROPONOWANY PRZEZ AA I MODEL MinNESOTA}

Proponowany przez Wspólnotę AA program zdrowienia wyłożony jest w Dwunastu Krokach. Zachowaniu jedności Wspólnoty służy Dwanaście Tradycji. Podstawowe informacje na temat Wspólnoty zawiera Preambuła:

"Anonimowi Alkoholicy są wspólnotą mężczyzn i kobiet, którzy dzielą się nawzajem doświadczeniem, siłą i nadzieją, aby rozwiązać swój wspólny problem i pomagać innym $\mathrm{w}$ wyzdrowieniu $\mathrm{z}$ alkoholizmu. Jedynym warunkiem uczestnictwa we Wspólnocie jest chęć zaprzestania picia. Nie ma w AA żadnych składek ani opłat, jesteśmy samowystarczalni poprzez własne, dobrowolne datki. Wspólnota AA nie jest związana z żadną sektą, wyznaniem, działalnością polityczną, organizacją lub instytucją, nie angażuje się w żadne publiczne polemiki, nie popiera ani nie zwalcza żadnych poglądów. Naszym podstawowym celem jest trwać w trzeźwości i pomagać innym alkoholikom w jej osiągnięciu”. Można też przeczytać, że „Zasady wypracowane przez AA są jedynie wytyczną dla ogólnego rozwoju" [21: 50-51].

Bliższe i bardziej szczegółowe zapoznanie się z programem Dwunastu Kroków, znajomość literatury z nim związanej, a szczególnie osobisty udział 
ipation in AA group meetings, allows us to conclude that the proposed program is available for virtually any alcoholic, regardless of their age, education, social status, or religion [1:288]. Meetings of AA groups may be closed (only for alcohol dependent persons) or open (anyone can participate). There are meetings in which everyone can speak (discussion meetings on a proposed topic) or meetings where previously selected persons share their experience (speaker meetings). There are also meetings devoted to AA's Twelve Steps, AA Traditions, AA Concepts, reading the "Big Book" or "Living Sober". There are meetings for beginners, information and organizational meetings, as well as meetings for young people, for women only or for LGBT people. In the interest of protecting those in authority, meetings are also organized for some professional groups, as for doctors, lawyers or only for therapists who do not want to talk about their problems in the presence of current or future patients ${ }^{8}$.

In the literature on the subject, there are numerous publications on religiousness and spirituality in AA and the "spiritual awakening" of AA members [32-38]. Contrary to some false opinions, it should be clearly emphasized that this is not a religious program [39].

Associating AA with religion results not only from the fact that AA's roots go back to the ideas of the Christian Oxford Groups, from which the concept for 6 Steps (out of 12) was taken, but also because the AA program mentions a "Higher Power" and God "as we understand Him". In addition, the cessation of drinking by AA cofounder Bill W. was the result of something, as Dr. Silkworth put it, like a "conversion" or in the opinion of William James, a spiritual experience or "religious experience", although Dr. Silkworth also wondered whether it could not be the result of psychotic experiences (hallucinations?). The atheist Bill W., who was once again in the hospital because of drinking alcohol, was known to shout in "spiritual agony" at night: "If there is a God, let Him show Himself!". And then, as he later described: "Suddenly the room lit up with a great white light. I was caught up into an ecstasy which there are no words to describe. It seemed to me, in my mind's eye, that I was on a mountain and that a wind not of air but of spirit was blowing. And then it burst upon me that

${ }^{8}$ I tried to organize AA meetings for our members of Polish Parliament, but without success. w spotkaniach (mityngach) grup AA pozwalają stwierdzić, że proponowany program jest dostępny praktycznie dla każdego alkoholika, bez względu na jego wiek, wykształcenie, status społeczny czy wyznawaną religię [1: 288]. Spotkania grup AA (powszechnie używane jest określenie „mityngi AA") mogą mieć charakter zamknięty (wyłącznie dla osób uzależnionych od alkoholu) lub otwarty (może uczestniczyć każdy), mogą się na nich wypowiadać wszyscy (mityngi dyskusyjne na zaproponowany temat) lub swoim doświadczeniem dzielą się tylko wytypowane wcześniej osoby (tzw. mityngi spikerskie), są też mityngi poświęcone Krokom AA, Tradycjom AA, Koncepcjom AA, poświęcone czytaniu „Wielkiej Księgi” czy „Życia w trzeźwości”. Są mityngi dla początkujących, mityngi informacyjne i organizacyjne, a także mityngi dla młodych, wyłącznie dla kobiet czy też osób LGBT. W trosce o ochronę autorytetu organizowane są również mityngi dla niektórych grup zawodowych, np. lekarzy, prawników czy wyłącznie dla terapeutów, którzy nie chcą mówić o swoich problemach w obecności aktualnych bądź przyszłych pacjentów ${ }^{8}$.

W literaturze przedmiotu można spotkać liczne publikacje na temat religijności i duchowości w AA oraz „duchowego przebudzenia” członków Wspólnoty [32-38]. Wbrew niektórym fałszywym opiniom należy jednak wyraźnie podkreślić, że nie jest to program religijny [39].

Łączenie AA z religią wynika nie tylko $\mathrm{z}$ faktu, że korzenie AA sięgają idei chrześcijańskich grup oksfordzkich, skąd zaczerpnięto pomysł na 6 (z 12) Kroków, ale także stąd, iż program AA wspomina o „Sile Wyższej” oraz o Bogu ,jakkolwiek Go pojmujemy". Dodatkowo zaprzestanie picia przez współzałożyciela AA, Billa W., było wynikiem czegoś w rodzaju „nawrócenia”, jak to określał dr Silkworth, przeżycia duchowego czy „doświadczenia religijnego" wg Williama Jamesa, chociaż dr Silkworth zastanawiał się również nad tym, czy nie mogło to być efektem przeżyć psychotycznych (halucynacji?). Ateista Bill W., który z powodu picia alkoholu znalazł się po raz kolejny w szpitalu, w „agonii duchowej” miał w nocy zawołać: „Jeśli Bóg istnieje, niech się ujawni”, i wówczas, jak to później opisał, „Nagle mój pokój rozbłysnął nieopisanym białym światłem. Opanowało mnie uniesienie nie do opisania. (...) oczyma duszy ujrzałem górę. Stałem na jej szczycie, a wiał wielki

\footnotetext{
${ }^{8}$ Próbowałem w swoim czasie zorganizować mityngi AA dla naszych parlamentarzystów, jednak bez powodzenia.
} 
I was a free man. (...) A great peace stole over me (...)" (Dublin Group, Inc. http://www.dubgrp.com/ content/william-james-bill-wilson-and-development-alcoholics-anonymous-aa). "He always said that after that experience, he never again doubted the existence of God. He never had another drink" [40: 130-131].

At the same time in his personal story Bill emphasized that AA was to help the alcoholic "find a power greater than yourself which will solve your problem (...) When, therefore, we speak to you of God, we mean your own conception of God. This applies, too, to other spiritual expressions which you find in this book. (...) Our book is meant to be suggestive only (...) Abandon yourself to God as you understand God" (Anonymous Press, https://anonpress.org/bb/Page_45.htm).

Although the spiritual (and not religious) nature of the Fellowship is emphasized, the association of AA with religion may result from many members being considered "hopeless alcoholics" who, after numerous unsuccessful attempts to free themselves from alcohol, see their cessation of drinking as a "miracle from God" and as evidence of God's presence or as "transcendental intervention" [41, 42]. In conclusion, it is worth remembering once more a part of the AA Preamble which clearly states that "AA is not allied with any sect, denomination, politics, organization or institution (...). Our primary purpose is to stay sober and help other alcoholics to achieve sobriety". At the same time, the Fifth Tradition clearly states that each AA group has but one primary purpose "to carry its message to the alcoholic who still suffers" [43].

The program proposed by Alcoholics Anonymous "makes it easier to gain insight into the essence of addiction and oneself, enables the analysis of interpersonal contacts, supports in exploring and enriching potential opportunities for one's own development and gives tips on how to achieve sobriety. In AA sobriety is understood in a much broader sense than just maintaining abstinence, because it also includes a changed way of thinking and feeling about oneself and others, and mature, and therefore 'sober' way of functioning in life. The goals formulated in the Twelve Steps are implemented by individual group members in an individual and often different way, and the 'steps' only propose the order of analyzing their own experiences and making changes" [44]. The importance of Alcoholics Anonymous is demonstrated wiatr (...). Wówczas nadeszła porażająca myśl: jesteś wolnym człowiekiem. (...) Ogarnął mnie wielki spokój (...) już nie musiałem się martwić”. „Po tym doświadczeniu już nigdy więcej nie wątpił $\mathrm{w}$ istnienie Boga. I nigdy więcej nie wypił ani kropli” [40: 130-131].

Jednocześnie w swoich wypowiedziach Bill podkreślał, że AA ma pomóc „w znalezieniu Siły Większej niż ty sam. Siły, która rozwiąże twój problem (...) Dlatego też, kiedy mówimy o Bogu, mamy na myśli twoje własne pojęcie Boga. Dotyczy to również wszystkich duchowych pojęć zawartych w tej książce. (...) A nasza książka zawiera wyłącznie sugestie (...) Oddaj się Bogu, takiemu jak Go sam pojmujesz" [21: 38-39, 143].

Chociaż podkreślany jest duchowy (a nie religijny) charakter Wspólnoty, do łączenia jej z instytucjami o charakterze religijnym może jednak też skłaniać fakt, że wielu członków Wspólnoty, uznawanych przez swoje otoczenie za „beznadziejnych alkoholików", po licznych nieudanych próbach uwolnienia się od alkoholu postrzega zaprzestanie przez siebie picia jako „cud od Boga”, dowód na obecność Boga czy „interwencję transcendentalną" [41, 42]. Kończąc ten temat, warto przypomnieć jeszcze fragment Preambuły AA, która mówi jednoznacznie, że: „Wspólnota AA nie jest związana z żadną sektą, wyznaniem, działalnością polityczną, organizacją lub instytucją (...). Naszym podstawowym celem jest trwać w trzeźwości i pomagać innym alkoholikom w jej osiągnięciu”. Jednocześnie Piąta Tradycja wyraźnie mówi, że główny cel AA to „nieść posłanie alkoholikowi, który jeszcze cierpi” [43].

Proponowany przez Wspólnotę „program ułatwia uzyskanie wglądu w istotę uzależnienia oraz w samego siebie, umożliwia analizę swoich kontaktów interpersonalnych, wspiera w poznawaniu i wzbogacaniu potencjalnych możliwości własnego rozwoju oraz daje wskazówki, w jaki sposób można osiągnąć trzeźwość. Trzeźwość rozumiana jest w AA znacznie szerzej niż samo utrzymywanie abstynencji, ponieważ obejmuje również zmieniony sposób myślenia, odczuwania siebie i innych oraz dojrzałe, a więc «trzeźwe» funkcjonowanie w życiu. Cele sformułowane w Dwunastu Krokach są realizowane przez poszczególnych członków grup w sposób indywidualny i często odmienny, a «kroki» proponują jedynie kolejność przeprowadzania analizy własnych doświadczeń i dokonywania zmian" [44]. O tym, jak ważną społecznie rolę 
by research conducted in 1990, which showed that as many as $9 \%$ of adult US residents have participated in AA meetings [45].

According to Irvin Yalom [46], when comparing the Twelve-Step program with the features of group therapy it can be stated that this program is characterized by the following:

- "hope - it is achieved by associating with other non-drinking alcoholics who show that dealing with the problem is possible,

- universality - thanks to the exchange of alcohol related experiences,

- information - by participating in various thematic meetings, informal conversations, and reading literature,

- imitation - as a result of the repetition of AA texts and rituals,

- learning - knowing about the concerns of the illness, associating with other people, learning about ways to maintain sobriety,

- catharsis - AA gives the opportunity of experiencing of strong emotional relief,

- consistency - identification with the experiences of others, engaging in less formal aspects of AA meetings" [1: 292].

The difference between participating in professional addiction psychotherapy programs and using the Twelve-Step program within the Fellowship of Alcoholics Anonymous relies on, among others, the fact that AA participants take full, individual responsibility for the course and quality of their healing process; they themselves adopt and verify their goals; and their knowledge of alcoholism (alcohol dependence) comes from other members of the Fellowship and literature recommended by AA. During AA meetings there is an exchange of experiences between participants. Knowledge and skills are expressed in a simple and understandable language and transferred through a common-sense way and the wisdom resulting from the life and the experiences of people who are recovering. At the same time, traditional sayings, proverbs, rituals and symbols are used. Unlike professional psychotherapeutic meetings, participation in AA is not limited by time and anyone can participate in them as long as they like.

The blind can also use the AA program. To facilitate access, the basic texts have been published in Braille, i.e. "Alcoholics Anonymous", "Twelve Steps and Twelve Traditions" and "Daily Reflections". odgrywa Wspólnota AA, świadczą przeprowadzone w 1990 r. badania, które wykazały, że aż 9\% dorosłych mieszkańców Stanów Zjednoczonych uczestniczyło w spotkaniach Wspólnoty AA [45].

Porównując program Dwunastu Kroków z cechami terapii grupowej wg Irvina Yaloma [46], można stwierdzić, że program ten charakteryzuje:

- „nadzieja - uzyskuje się ją poprzez obcowanie z innymi niepijącymi alkoholikami, którzy pokazują, że poradzenie sobie z problemem jest możliwe,

- uniwersalność - dzięki wymianie doświadczeń związanych z alkoholem,

- informacja - poprzez udział w różnotematycznych mityngach i nieformalnych rozmowach oraz czytaniu literatury,

- naśladownictwo - dzięki powtarzalności tekstów i rytuałów AA,

- uczenie się - dotyczy poznawania swojej choroby, obcowania $\mathrm{z}$ innymi ludźmi, poznawania sposobów utrzymywania trzeźwości,

- katharsis - AA daje możliwość jej przeżycia,

- spójność - dzięki utożsamianiu się z doświadczeniami innych, angażowaniu się w mniej formalne aspekty mityngów AA" [1:292].

Różnica między uczestniczeniem w profesjonalnych programach psychoterapii uzależnień a korzystaniem z programu Dwunastu Kroków, w ramach Wspólnoty AA, polega m.in. na tym, że uczestnicy Wspólnoty biorą pełną, indywidualną odpowiedzialność za przebieg i jakość procesu swojego zdrowienia, sami przyjmują i weryfikują stawiane przed sobą cele, a ich wiedza na temat alkoholizmu (uzależnienia od alkoholu) pochodzi od innych członków Wspólnoty oraz z literatury zalecanej przez Wspólnotę. Podczas spotkań grupy AA (mityngów) dochodzi do wymiany doświadczeń między uczestnikami, a wiedza i umiejętności są przekazywane prostym i zrozumiałym dla wszystkich językiem, w sposób zdroworozsądkowy, wynikający $\mathrm{z}$ mądrości życiowej i z doświadczeń osób zdrowiejących. Jednocześnie wykorzystywane są tradycyjne powiedzonka, przysłowia, rytuały i symbole. W odróżnieniu od profesjonalnych spotkań psychoterapeutycznych, udział w spotkaniach Wspólnoty AA nie jest ograniczony czasowo i każdy może $\mathrm{z}$ nich korzystać tak długo, jak tylko zechce.

Z programu AA mogą korzystać także osoby niewidome, a dla ułatwienia im dostępu do literatury zostały wydane w języku Braille’a podstawowe pozycje, tj. „Anonimowi Alkoholicy”, „Dwanaście Kroków i Dwanaście Tradycji” oraz „Codzienne refleksje”. 
In my opinion, the best treatment for a person with an alcohol use disorder is the use of both professional therapy and the AA Fellowship program. Work with a sponsor ${ }^{9}$ in AA should be treated similarly to work with a psychotherapist. On the other hand, using the help of two specialists at the same time (specialist-theoretician, i.e. therapist, and a specialist-practitioner, i.e. a sponsor from AA), is similar to treating the same disease by two different doctors, which can do more harm than good. For this reason, I suggest that my patients first participate in the addiction psychotherapy program, where they acquire basic knowledge about themselves and their illness in a structured manner, as well as the skills necessary to stop drinking and live a sober life, and then continue the recovery process in AA, under the guidance of the sponsor.

The most known "contribution" of Alcoholics Anonymous to the treatment of alcohol dependent people, and later also of other psychoactive substances, is the Minnesota Model. This approach was developed in the late 1940s at the Willmar Hospital. It was the only psychiatric hospital in the State of Minnesota (1,800 beds) that accommodated alcoholics, with 100 beds dedicated for this purpose. Two hospital employees, a doctor (Nelson Bradley) and an "adviser" (Daniel Anderson), prepared a program for the treatment of hospitalized alcoholics based on AA experience [47-49]. Initial assumptions of the model relied on a combination of experiences of professionals and recovering alcoholics from AA with an individualized approach to treatment and active participation of the patient's family. The inpatient treatment was carried out in an intensive (7 days a week) 28-day program. The Minnesota Model was described as a method characterized by a "multidisciplinary approach to chronic disease" and treated as "inseparable from the program, practice and philosophy of Alcoholics Anonymous" [50].

\section{- The history of AlCoHolics ANONYMOUS IN POLAND}

The first mention of Alcoholics Anonymous in Poland was in a handbook for doctors entitled “Treatment of Chronic Alcoholism” by Dr. Henryk

\footnotetext{
${ }^{9}$ The sponsor is a more experienced AA member who teaches other alcoholics how to use the Twelve-Step program and how to put it into practice.
}

Moim zdaniem, najlepsze dla osoby z zaburzeniami używania alkoholu jest korzystanie zarówno z terapii profesjonalnej, jak i z programu Wspólnoty AA. Pracę ze sponsorem ${ }^{9}$ w AA należy traktować podobnie jak pracę $\mathrm{z}$ psychoterapeutą. Natomiast korzystanie w tym samym czasie z pomocy dwóch specjalistów (specjalisty-teoretyka, tj. terapeuty, i specjalisty-praktyka, tj. sponsora z AA), podobnie jak leczenie tego samego schorzenia przez dwóch różnych lekarzy, może przynieść więcej szkody niż pożytku. $Z$ tego powodu swoim pacjentom proponuję uczestniczenie najpierw $\mathrm{w}$ programie psychoterapii uzależnień, gdzie w sposób ustrukturalizowany zdobywają podstawową wiedzę o sobie i swojej chorobie, a także umiejętności niezbędne do zaprzestania picia i do trzeźwego życia, a następnie - kontynuację procesu zdrowienia we Wspólnocie AA „pod okiem” sponsora.

Najbardziej znanym „wkładem” Wspólnoty AA w leczenie osób uzależnionych od alkoholu, a później również od innych substancji psychoaktywnych, jest tzw. model Minnesota. To podejście zostało wypracowane pod koniec lat 40. w szpitalu w Willmar. Był to wówczas jedyny w amerykańskim stanie Minnesota szpital psychiatryczny (1800 lóżek) przyjmujący alkoholików, w którym wydzielono dla nich 100 łóżek. Dwaj pracownicy szpitala - lekarz (Nelson Bradley) i „doradca” (Daniel Anderson) opierając się na doświadczeniach AA, przygotowali program leczenia hospitalizowanych alkoholików [47-49]. Wstępne założenia modelu polegały na połączeniu doświadczeń profesjonalistów i alkoholików zdrowiejących przy pomocy Wspólnoty AA, na zindywidualizowanym podejściu do leczenia $\mathrm{z}$ aktywnym udziałem rodziny pacjenta. Leczenie realizowano $\mathrm{w}$ warunkach intensywnego (7 dni w tygodniu), stacjonarnego, 28-dniowego programu. Model Minnesota był opisywany jako metoda charakteryzująca się „multidyscyplinarnym podejściem do choroby przewlekłej" i traktowany jako „nierozerwalnie związany z programem, praktyką i filozofią Anonimowych Alkoholików” [50].

\section{HISTORIA WSPÓlNOTY AA W POLsce}

Pierwsza w Polsce wzmianka na temat Wspólnoty AA pojawiła się w 1950 r. w podręczniku dla

\footnotetext{
${ }^{9}$ Sponsor w AA to bardziej doświadczony alkoholik, który uczy korzystania z programu Dwunastu Kroków i praktycznego wdrażania go w życie.
} 
Zajączkowski, a psychiatrist and neurologist published in 1950. Dr. Zajączkowski was the creator of the Main Mental Health Clinic in Warsaw, and in 1948 he founded the Patients' Club, which can be considered the prototype of a self-help group in our country. Dr. Zajączkowski wrote that "The fact of the existence of groups created by former alcoholics in the various organizational forms of abstinent associations, like Alcoholics Anonymous, is the best proof that alcoholics are perfectly capable of creating a high-level [psychotherapeutic - author's note] group" [51]. Shortly after the political thaw in 1956, after returning from a scholarship in London, Dr. Zbigniew Wierzbicki, a then young sociologist from the Poznan University of Economics, described in detail the assumptions of the program of Alcoholics Anonymous in the journal Zdrowie i Trzeźwość (Health and Sobriety) (December 1957), and then introduced them to the employees of the alcohol outpatient clinic in Poznań, with which he cooperated. It was the first attempt to form an AA group in Poznań [52]. In the 1960s, a similar attempt was made in Warsaw by neurologist Tadeusz Kulisiewicz, MD. It was an unsuccessful, as Dr. Kulisiewicz reported, "some institutions absolutely did not allow this movement in the country. They were disturbed by (...) the mention of a Higher Power" [53]. In 1964, the psychologist Maria Grabowska from alcohol outpatient clinic in Poznań informed General Service Office (GSO) in New York of the therapeutic group that met on Wednesdays (the so-called Wednesday group) as the AA group "Eleusis". The group was added to the GSO worldwide list of AA groups. The first two groups, which had meetings without non-alcoholics present and therefore could be called genuine Alcoholics Anonymous groups, emerged in Poznań not earlier than in the 1970s. In fact the "Eleusis" group was created in 1974 on the basis of a therapeutic group led by Maria Matuszewska (who had replaced Maria Grabowska in 1971), while the "Ster" group, inspired by psychiatrist Dr. Danuta Dudrak, was founded in 1976 [52]. The third Polish AA group "Znicz", at the Abstinence Club "Znicz" in Będzin, was founded by an alcoholic, Sławek S. (a participant of AA meetings in Poznan and the first spokesman in Polish AA Fellowship). The fourth (or fifth?) group called "Odrodzenie" was founded in Warsaw in May 1980 and met at the Psychoneurological Institute in the Alcoholism Treatment Department, of which I was in charge at lekarzy pt. „Leczenie alkoholizmu przewlekłego” autorstwa dr. Henryka Zajączkowskiego, psychiatry i neurologa. Był on twórcą Głównej Poradni Zdrowia Psychicznego w Warszawie, a w 1948 r. założył przy niej Klub Pacjenta, który można uznać za pierwowzór grupy samopomocowej w naszym kraju. Doktor Zajączkowski napisał: „Fakt istnienia grup stworzonych $\mathrm{z}$ byłych alkoholików $\mathrm{w}$ najrozmaitszych postaciach organizacyjnych stowarzyszeń abstynenckich, jak na przykład Alcoholics Anonymous, jest najlepszym dowodem, że alkoholicy są najzupełniej zdolni do stworzenia grupy (psychoterapeutycznej - przyp. autora) na wysokim poziomie" [51]. Wkrótce po odwilży politycznej 1956 r., dr Zbigniew Wierzbicki, wówczas młody socjolog z Wyższej Szkoły Ekonomicznej w Poznaniu, po powrocie ze stypendium w Londynie opisał szerzej założenia Wspólnoty AA w czasopiśmie Zdrowie i Trzeźwość (grudzień 1957 r.), a następnie zapoznał $\mathrm{z}$ nimi pracowników poradni przeciwalkoholowej w Poznaniu, z którą współpracował. Była to pierwsza „przymiarka” do utworzenia grupy AA w Poznaniu [52]. Z kolei w latach 60. podobną próbę podjął $\mathrm{w}$ Warszawie neuro$\log$, dr med. Tadeusz Kulisiewicz. Była to próba nieudana, gdyż, jak relacjonował dr Kulisiewicz, „pewne instytucje absolutnie nie dopuściły do zorganizowania ruchu w kraju. Przeszkadzała im (...) wzmianka o Sile Wyższej" [53]. W 1964 r. spotykająca się w środy grupa terapeutyczna (tzw. grupa środowa) została zgłoszona przez psycholog poradni odwykowej w Poznaniu, Marię Grabowską, do GSO w Nowym Jorku jako grupa AA „Eleusis” i znalazła się w prowadzonym przez GSO światowym spisie grup AA. Dwie pierwsze grupy, prowadzące mityngi bez obecności nie-alkoholików, które można nazwać prawdziwymi grupami AA, powstały w Poznaniu dopiero w latach 70. Grupa „Eleusis” została utworzona w 1974 r. na bazie grupy terapeutycznej prowadzonej przez Marię Matuszewską (zastąpiła w 1971 r. Marię Grabowską), a grupa „Ster” powstała w 1976 r. z inspiracji psychiatry dr Danuty Dudrak [52]. Trzecią polską grupę AA „Znicz”, przy Klubie Abstynenta „Znicz” w Będzinie, założył alkoholik Sławek S. (uczestnik mityngów AA w Poznaniu i pierwszy Rzecznik w polskiej Wspólnocie AA). Czwarta (lub piąta?) grupa pod nazwą „Odrodzenie” powstała w Warszawie w maju 1980 r. i spotykała się w Instytucie Psychoneurologicznym na terenie Oddziału Odwykowego, którym wówczas kierowałem [54-56]. 
the time [54-56]. Despite some controversy, 1974 was recognized as the year Alcoholics Anonymous Fellowship was established in Poland. For many subsequent years (and as is still the case today), the Fellowship of Alcoholics Anonymous and AA groups were confused with abstinence clubs, which wrongly and probably unlawfully used the name "AA club" (Abstinent Anonymous, Anonymous Alcoholics, Abstinent Alcoholics).

The first Polish-language AA group in the world was founded in 1966 in Chicago. There, in a hospital run by the Congregation of the Resurrection ('Resurrectionists') ${ }^{10}$, which was attended to many Polish alcoholics, the first Polish-language meeting of AA took place outside of Poland. The hospital management decided that the AA group would be very helpful in the treatment of Polish-speaking alcoholic patients. At their request, Józef G. and a certain unspecified "psychiatrist" (a hospital employee or patient?) established the group. Soon, Józef (nicknamed Papa Joe and born in the United States), who had 10 years of abstinence at the time as a result of attending AA English-language meetings, joined the group. After two years, he took over as head of the group. Soon the group had to change the meeting place because they could no longer afford to pay the rent, which had been increased by the hospital authorities. Papa Joe commented that "first they wanted us to help them, and then told us to pay extra for it"11.

In 1982, the national conference of abstinence clubs was organized by the Psychoneurological Institute (later renamed the Institute of Psychiatry and Neurology). At the initiative of members of the Warsaw AA group "Odrodzenie", participants of this conference from the AA Fellowship met separately as representatives of 13 AA groups existing at that time in Poland. The AA Provisional National Service Committee was established, entrusting it with, among others, the task of organizing a nationwide AA congress. The $1^{\text {st }}$ National AA Congress took place in Poznań in 1984; representatives from 34 groups attended. "The Status and Electoral Law of the AA National Service Board in Poland" was adopted there, and the Trustees, the so-called Seven, were chosen [52: 182]. Soon, as early as 1985,

\footnotetext{
${ }^{10}$ Congregation of the Resurrection of our Lord Jesus Christ.

${ }^{11}$ Józef, who was called Papa Joe by those in AA, told the author about the creation and activity of this group in Chicago in 1986.
}

Pomimo pewnych kontrowersji, rok 1974 został uznany rokiem powstania Wspólnoty AA w Polsce. Przez wiele kolejnych lat (zdarza się to nawet jeszcze dzisiaj) grupy AA i Wspólnota AA bywały mylone z klubami abstynenta, które niesłusznie i chyba bezprawnie posługiwały się nazwą „klub AA" (Anonimowych Abstynentów, Anonimowych Alkoholików, Alkoholików Abstynentów).

Pierwsza polskojęzyczna grupa AA na świecie powstała w 1966 r. w Chicago. Tam też, w szpitalu prowadzonym przez Zgromadzenie Zmartwychwstania Pańskiego („Zmartwychwstańcy”) ${ }^{10}$, do którego trafiało wielu Polaków-alkoholików, odbył się pierwszy polskojęzyczny mityng AA poza granicami Polski. Dyrekcja szpitala uznała bowiem, że grupa AA będzie bardzo pomocna w leczeniu mówiących po polsku pacjentów-alkoholików. $\mathrm{Na}$ jej prośbę Józef G. i pewien nieokreślony bliżej „psychiatra" (pracownik szpitala albo pacjent?) założyli taką grupę. Wkrótce dołączył do niej Józef (nazywany Papa Joe), urodzony w Stanach, który miał wówczas 10-letni staż abstynencki dzięki uczęszczaniu na angielskojęzyczne mityngi AA. Po dwóch latach przejął prowadzenie grupy. Wkrótce grupa musiała zmienić miejsce spotkań, nie było jej bowiem stać na opłacanie podwyższonego przez władze szpitalne czynszu. Papa Joe tak to skomentował: „Najpierw chcieli, żebyśmy im pomagali, a później kazali nam jeszcze do tego dopłacać"11.

W 1982 r., podczas zorganizowanej przez Instytut Psychoneurologiczny (przemianowany później na Instytut Psychiatrii i Neurologii) krajowej konferencji klubów abstynenckich, z inicjatywy członków warszawskiej grupy AA „Odrodzenie" odbyło się spotkanie biorących udział w tej konferencji członków Wspólnoty AA. W spotkaniu uczestniczyli przedstawiciele istniejących wówczas na terenie Polski 13 grup AA. Powołano Tymczasowy Krajowy Komitet Służby AA, powierzając mu m.in. zadanie zorganizowania ogólnopolskiego zjazdu AA. I Krajowy Zjazd AA odbył się w Poznaniu w 1984 r. Wzięli w nim udział mandatariusze z 34 grup. Uchwalono tam „Status i ordynację wyborczą Służby Krajowej AA w Polsce”, wybrano Ciało Powiernicze, tzw. Siódemkę [52: 182]. Wkrótce, bo już w 1985 r.,

\footnotetext{
${ }^{10}$ Congregation of the Resurrection of our Lord Jesus Christ.

${ }^{11} \mathrm{O}$ powstaniu i działalności tej grupy opowiedział autorowi w 1986 r. w Chicago Józef, nazywany przez miejscowych AA-owców Papa Joe.
} 
the first issue of the bulletin Ruch Anonimowych Alkoholików (precursor of today's Zdrój), the Polish equivalent of Grapevine (AA Grapevine, International Journal of Alcoholics Anonymous) was published. By 1988, 238 AA groups and 9 intergroups (coordinating the activities of local AA groups) were established in Poland, and Polish-language AA groups abroad were recognized as an integral part of AA in Poland. In 1991 there were already 470 AA groups and 10 intergroups; in $1994-858$ and 23; in 1996 - 1110 and 46; in 1999 - 1469 and 56 respectively [57: 565-574]. Currently, there are around 2,800 Alcoholics Anonymous groups throughout Poland, including around 240 in prisons ${ }^{12}$.

In 1995, the Foundation AA National Service Office in Poland was registered, which gave the AA groups in Poland legal services and enabled them the ability e.g. to publish AA literature legally ${ }^{13}$.

The late Prof. Wiktor Osiatyński (a constitutional lawyer and AA member since 1983) played an important role in the development of Alcoholics Anonymous in Poland during the 1980s and 1990s. He translated part of the basic AA literature into Polish and was also a link between Poland and the United States [58]. He was also the first so-called public figure who spoke openly about his alcoholism on a television program in 1991.

However, not all psychiatrists and doctors were convinced of this form of assistance to alcohol dependent persons and the use of psychotherapy in their treatment. An example would be the attitude of Prof. Tadeusz Bilikiewicz, a leading Polish psychiatrist from the period immediately following World War II who was an active participant in the anti-alcohol movement, along with such psychiatrists like Witold Chodźko or Rafał Radziwiłłowicz. Although he agreed that alcoholism is a disease ("mainly a psychiatric and social problem"), what he considered most effective was a so-called forced treatment of alcoholics and their "rehabilitation" through work. He was also a supporter of the idea of abstinence and promoted the introduction of a prohibition project he designed, prohibiting the production of alcoholic beverages, because he assumed that this should significantly

12 The first Polish AA group in prison was established in 1987 in ZK Siedlce, on the initiative of the psychologist Tadeusz Paciorek.

${ }^{13}$ The founders were the psychologist Maria Matuszewska from Poznan and the medical doctor Bohdan Woronowicz from Warsaw. ukazał się pierwszy numer biuletynu Ruch Anonimowych Alkoholików (prekursora dzisiejszego Zdroju), polskiego odpowiednika Grapevine. Do 1988 r. powstało w Polsce 238 grup AA i 9 intergrup (koordynujących działania miejscowych grup AA), a polskojęzyczne grupy AA za granicą uznano za integralną część W spólnoty AA w Polsce. W 1991 r. było już 470 grup AA i 10 intergrup, a w następnych latach odpowiednio: w 1994 r. - 858 i 23, w 1996 r. - 1110 i 46, w 1999 r. - 1469 i 56 [57: 565-574]. Obecnie na terenie niemal całej Polski funkcjonuje ok. 2800 grup AA, w tym ok. 240 w zakładach karnych ${ }^{12}$.

W 1995 r. zarejestrowana została Fundacja Biuro Służby Krajowej AA w Polsce, dzięki czemu Wspólnota AA uzyskała możliwość obsługi prawnej i mogła np. legalnie wydawać literaturę ${ }^{13}$.

Ważną rolę w rozwoju polskiego ruchu AA w latach 80. i 90. odegrał wspomniany wcześniej, nieżyjący już prof. Wiktor Osiatyński (prawnik-konstytucjonalista, członek Wspólnoty AA od 1983 r.), który m.in. przetłumaczył na język polski część podstawowej literatury AA i jednocześnie był łącznikiem między Polską a Stanami Zjednoczonymi [58]. Był także pierwszą tzw. publiczną osobą, która w 1991 r. w programie telewizyjnym powiedziała otwarcie o swoim alkoholizmie.

Nie wszyscy psychiatrzy i nie wszyscy lekarze byli jednak przekonani do tej formy pomocy osobom uzależnionym od alkoholu i do stosowania psychoterapii $\mathrm{w}$ ich leczeniu. Przykładem może być postawa prof. Tadeusza Bilikiewicza, czołowego polskiego psychiatry z okresu bezpośrednio po II wojnie światowej i jednocześnie, obok takich psychiatrów, jak Witold Chodźko czy Rafał Radziwiłłowicz, aktywnego uczestnika ruchu antyalkoholowego. Wprawdzie zgadzał się z tym, że alkoholizm jest chorobą („głównie problemem psychiatryczno-społecznym"), ale za najbardziej skuteczne uważał tzw. przymusowe leczenie alkoholików i ich „rehabilitację” przez pracę. Był jednocześnie zwolennikiem idei abstynencji i forsował wprowadzenie ustawy prohibicyjnej własnego projektu, zakazującej produkowania napojów alkoholowych, wychodził bowiem z założenia, że powinno to $\mathrm{w}$ istotnym stopniu rozwiązać problem

\footnotetext{
${ }^{12}$ Pierwsza polska grupa AA w zakładzie karnym powstała w 1987 r. w ZK Siedlce, z inicjatywy psychologa Tadeusza Paciorka.

${ }^{13}$ Fundatorami zostali psycholog Maria Matuszewska z Poznania i dr n. med. Bohdan Woronowicz z Warszawy.
} 
solve the problem of alcoholism. Dr. Kulisiewicz considered this proposal to be "absurd" and agreed with the other leading contemporary Polish "alkoholog" and psychiatrist, Dr. Leon Hrynkiewicz (director of the psychiatric hospital in Wrocław). In his opinion, no doctor should ever make this kind of proposal. In the opinion of Dr. Hrynkiewicz "in the fight against alcoholism the AA movement is playing a major role in the entire world (...) and we constantly undervalue it". Professor Bilikiewicz also believed that dependent persons should not go unpunished, but at the same time proclaimed that "drinkers are victims, not perpetrators (...) it is not so much the drinkers who deserve punishment, but producers and sellers" of alcoholic beverages [59].

There were also extreme and radical attitudes among doctors, for example, the call to organize forced labor camps for alcoholics, or denying the morbid nature of alcoholism, putting alcoholism and drug addiction on a par with "social parasitism" and treating them as "specific crimes requiring deliberate social condemnation" [52: 97-98].

\section{- Adaptation of the Minnesota MODEL IN POLAND}

In Poland, the elements of the Minnesota Model mentioned earlier were used for the first time in the mid-1980s in the Alcoholism Treatment Department of the Institute of Psychiatry and Neurology in Warsaw (today the Dependence Therapy Centre IPiN). At that time, we were the first institution in this part of Europe where psychotherapy was the basis of the program and in which we did not (unlike most of the then Polish alcohol treatment facilities) use aversion therapy, i.e. disulfiram (Anticol, Esperal) or the so-called ergotherapy, i.e. unpaid work for the hospital. Patients who had come to us for treatment from all over Poland often called us after they had returned home and complained that in their alcohol outpatient clinics they did not have psychotherapeutic support but were being "coerced" to take Anticol or Esperal. Therefore, they refused to continue treatment in these facilities.

In this situation, it became important to find another type of support for patients who were completing treatment. The alternative was to take advantage of the experiences of Alcoholics Anonymous Fellowship, knowledge of which was not widespread at that time. This involved alkoholizmu. Ta propozycja została uznana przez dr. Kulisiewicza za „absurdalną”, z czym zgadzał się również inny ówczesny czołowy polski „alkoholog" i psychiatra - dr Leon Hrynkiewicz (dyrektor szpitala psychiatrycznego we Wrocławiu). Jego zdaniem taka propozycja nie powinna wychodzić z ust lekarza. W opinii dr. Hrynkiewicza „w walce $\mathrm{z}$ alkoholizmem poważną rolę $\mathrm{w}$ całym świecie odgrywa ruch AA (...) u nas ciągle niedoceniany". Profesor Bilikiewicz uważał też, że osoby uzależnione nie powinny być bezkarne, ale jednocześnie głosił, że „pijący są ofiarami, a nie sprawcami (...) na kary zasługują nie tyle pijacy, co producenci i sprzedawcy" napojów alkoholowych [59].

Wśród lekarzy zdarzały się też postawy skrajne i radykalne, np. nawoływanie do organizowania obozów pracy przymusowej dla alkoholików czy negowanie chorobowego charakteru alkoholizmu, stawianie alkoholizmu oraz narkomanii na równi ze "społecznym pasożytnictwem” i traktowanie ich jako „szczególne przestępstwa wymagające świadomego potępienia społecznego" [52: 97-98].

\section{- AdAPtACja modelu Minnesota W POLSCE}

W Polsce elementy wspomnianego już wcześniej modelu Minnesota zostały zastosowane po raz pierwszy $\mathrm{w}$ połowie lat 80 . w prowadzonym przeze mnie Oddziale Odwykowym Instytutu Psychiatrii i Neurologii w Warszawie (dzisiejszym Ośrodku Terapii Uzależnień IPiN). Byliśmy wówczas pierwszą, w tej części Europy, placówką, w której podstawę programu stanowiła psychoterapia i w której nie stosowaliśmy (w odróżnieniu od większości ówczesnych polskich placówek odwykowych) terapii awersyjnej, tj. disulfiramu (Anticolu, Esperalu) ani tzw. ergoterapii, czyli nieodpłatnej pracy na rzecz szpitala. Pacjenci przyjeżdżający do nas na leczenie $z$ terenu całej Polski po powrocie do domu często dzwonili i skarżyli się, że w macierzystych poradniach odwykowych nie mają wsparcia psychoterapeutycznego, natomiast są "przymuszani” do przyjmowania Anticolu lub do „Wszywania” Esperalu. W związku z tym nie chcieli dalej leczyć się w tych placówkach.

W tej sytuacji potrzebą chwili stało się znalezienie innego rodzaju wsparcia dla pacjentów kończących leczenie. Alternatywą było skorzystanie z niezbyt rozpowszechnionych jeszcze wówczas doświadczeń Wspólnoty AA. Wiązało się to z pod- 
attempting to teach our patients the AA program so that it would be possible to continue the healing process in the direction we recommended. With the help of more experienced AA members (employed as full-time occupational therapy instructors ${ }^{14}$ ), we began to acquaint patients with the AA Steps and recommend participation in AA group meetings. This made it possible to continue the recovery process by "working on steps" in the place of residence. On this occasion, our former patients contributed to the development of the Fellowship, often establishing new AA groups in their area.

The inclusion of elements of the Minnesota Model in the therapeutic program was not easy at all. For example, inviting one of our former patients, a recovering alcoholic, to become a member of therapeutic team, met with the protests of some psychologists working in the ward. It was alleged that a member of the therapeutic team should not be a person whose therapeutic skills resulted solely from the fact of undergoing their own therapy and from the knowledge of the AA Twelve-Step program through participation in the AA Fellowship. I also perceived such an attitude as a struggle for "rule over people's souls". Psychologists were somewhat reassured by the assurance that the new team member would deal exclusively with introducing patients to the Twelve-Step program and at the same time would be an example that one can live with dignity without alcohol. Years later, during my stay in the United States, that I visited therapeutic centers where the staff consists of professionally trained recovering alcoholics only, and in some of these centers I was the only non-alcoholic and psychiatrist, which made me stand out as suspicious.

At that time, recovering alcoholics did not yet have the opportunity to undergo professional training in Poland. Over time, the situation normalized and alcoholics could be trained and later become full members of therapeutic teams in many addiction treatment centers in Poland.

An extremely valuable opportunity to continue the recovery process was the two-week therapeutic stays we organized in Strzyżyna outside Warsaw (at the Training and Rehabilitation Cen-

\footnotetext{
${ }^{14}$ Only after some time were we able to convince the Ministry of Health to introduce instructors of recovery therapy, and later, instructors of dependency therapy.
}

jęciem próby uczenia naszych pacjentów programu Wspólnoty, aby możliwe było kontynuowanie procesu zdrowienia w zalecanym przez nas kierunku. Przy pomocy bardziej doświadczonych członków Wspólnoty (zatrudnionych na etatach instruktorów terapii zajęciowej ${ }^{14}$ ) zaczęliśmy zaznajamiać pacjentów oddziału odwykowego z Krokami AA i zalecać uczestnictwo w spotkaniach grup AA. To umożliwiało kontynuowanie procesu zdrowienia przez „pracę nad krokami” w miejscu zamieszkania. Przy tej okazji nasi byli pacjenci przyczyniali się do rozwoju Wspólnoty, zakładając niejednokrotnie nowe grupy AA w swojej okolicy.

Włączenie elementów modelu Minnesota do programu terapeutycznego nie było proste, bo np. zaproszenie do współpracy, w charakterze członka zespołu terapeutycznego, jednego ze zdrowiejących alkoholików, naszego byłego pacjenta, spotkało się z protestami niektórych psychologów pracujących na oddziale. Stawiano mi zarzuty, że członkiem zespołu terapeutycznego nie powinna być osoba, której umiejętności terapeutyczne wynikają wyłącznie z faktu odbycia własnej terapii i ze znajomości programu Dwunastu Kroków AA dzięki uczestniczeniu we Wspólnocie AA. Taką postawę odbierałem też jako walkę o „rząd dusz”. Psychologów nieco uspokoiło zapewnienie, że nowy członek zespołu zajmie się wyłącznie przybliżaniem pacjentom programu Dwunastu Kroków i jednocześnie będzie przykładem, że można godnie żyć bez alkoholu. Okazało się, choć takiej pewności wówczas nie miałem, że patrząc z perspektywy czasu, decyzja o zatrudnianiu trzeźwiejących alkoholików była słuszna. Po latach, podczas pobytu w Stanach Zjednoczonych, odwiedziłem ośrodki terapeutyczne, gdzie personel stanowili przeszkoleni profesjonalnie zdrowiejący alkoholicy, a w niektórych byłem jedynym nie-alkoholikiem i do tego psychiatrą, co powodowało, że patrzono na mnie podejrzliwie.

W owych czasach zdrowiejący alkoholicy nie mieli jeszcze w Polsce możliwości odbycia profesjonalnego szkolenia. Z czasem sytuacja unormowała się, alkoholicy mogli się szkolić i stawali się później pełnoprawnymi członkami zespołów terapeutycznych $\mathrm{w}$ wielu placówkach lecznictwa odwykowego w Polsce.

Niezwykle cenną możliwością kontynuowania procesu zdrowienia były organizowane przez nas

${ }^{14}$ Dopiero po pewnym czasie udało się przekonać Ministerstwo Zdrowia do wprowadzenia etatów instruktorów terapii odwykowej, a później instruktorów terapii uzależnień. 
ter of the Institute of Psychiatry and Neurology), during which, with the help of more experienced members of the AA and Al-Anon fellowships, we familiarized patients with the Twelve-Step program [60]. Between 1987 and 2009, thousands of alcohol dependent persons and their relatives from all over Poland benefited from this form of therapy. We also ran several Russian language groups, and because of the similarity of languages, we accepted several Slovaks, and even a Hungarian who spoke Polish (funds from the Stefan Batory Foundation were used to finance programs for foreigners). Unfortunately, this idea collapsed along with changes in health care financing and new standards that were set for addiction treatment centers in Poland. Also, attempts to convince decision makers from the Health Fund and later the National Health Fund about the effectiveness of this form of treatment and the savings associated with it have also failed.

The therapy program developed in Strzyżyna between the 1980s and 1990s was unique not just in Poland. For a period of 2 weeks, classes took place every day from morning to late evening (9-10 hours a day). Selected leaders (people with longer periods of recovery in AA or Al-Anon), under the supervision of a professional coordinator, led small groups discussing the AA and Al-Anon Steps according to materials-guides prepared by us (groups discussing Steps 1-3, 4-5, 6-7, 8-10 and 11-12). Alcohol dependent and co-dependent persons (from AA and Al-Anon) worked on the first 5 Steps in separate groups, while from the $6^{\text {th }}$ Step, the groups were mixed. Every evening an open AA or Al-Anon meeting was held in which all participants and staff attended, followed by a summary of the day, that is a joint Step $10^{\text {th }}$. Only once a year could a person take part in this type of program and learn the next Steps in the following years. In the meantime, we recommended that participants deepen their knowledge of the program at AA or Al-Anon meetings where they live. For many years, this form of therapy replaced working with a sponsor for many people.

The cooperation of alcohol outpatient treatment system with Alcoholics Anonymous was different in Poland and largely depended on the attitude of the facility's management towards the Alcoholics Anonymous Fellowship. There were people who understood and accepted the AA program and also those who were re- dwutygodniowe turnusy terapeutyczne w Strzyżynie (w Ośrodku Szkoleniowo-Rehabilitacyjnym Instytutu Psychiatrii i Neurologii), podczas których, z pomocą bardziej doświadczonych członków Wspólnoty AA i Al-Anon, zapoznawaliśmy pacjentów z programem Dwunastu Kroków [60]. W latach 1987-2009 z tej formy terapii skorzystały tysiące osób uzależnionych i ich bliskich $\mathrm{z}$ terenu całej Polski. Prowadziliśmy też kilka grup w języku rosyjskim, a z racji podobieństwa języków przyjęliśmy kilku Słowaków, a nawet Węgra mówiącego po polsku (pobyty obcokrajowców były finansowane ze środków Fundacji Stefana Batorego). Niestety idea ta upadła wraz ze zmianami w finansowaniu opieki zdrowotnej i nowymi standardami, jakie zostały ustalone dla placówek lecznictwa odwykowego w Polsce. Próby przekonania decydentów z Kas Chorych, a później z Narodowego Funduszu Zdrowia o skuteczności takich turnusów i oszczędnościach z nimi związanych zakończyły się niestety niepowodzeniem.

Wypracowany w Strzyżynie program terapii był w latach 80. i 90. programem unikatowym nie tylko w skali Polski. Przez 2 tygodnie zajęcia odbywały się codziennie od rana do późnych godzin wieczornych (9-10 godzin dziennie). Wybrani liderzy (osoby z AA lub Al-Anon z dłuższym stażem w zdrowieniu), pod nadzorem koordynatora-profesjonalisty, prowadzili małe grupy omawiające wspólnie kolejne Kroki AA i Al-Anon wg przygotowanych przez nas materiałów - przewodników (grupa omawiająca Kroki 1-3, 4-5, 6-7, 8-10 i 11-12). Pierwsze 5 Kroków osoby uzależnione i współuzależnione (z AA i z Al-Anon) „przechodziły” oddzielnie, natomiast od 6. Kroku grupy miały charakter mieszany. Codziennie wieczorem odbywał się też otwarty mityng AA lub Al-Anon, w którym brali udział wszyscy uczestnicy turnusu i personel, następnie podsumowanie dnia, czyli wspólny 10 . Krok. W takim turnusie można było wziąć udział tylko raz w roku i w kolejnych latach poznawać kolejne Kroki. W międzyczasie zalecaliśmy pogłębianie znajomości programu na mityngach AA lub Al-Anon w miejscu zamieszkania. Przez wiele lat ta forma terapii zastępowała wielu osobom pracę ze sponsorem.

Współpraca ambulatoryjnego lecznictwa uzależnień ze Wspólnotą AA przebiegała w Polsce różnie i w znacznym stopniu zależała od stosunku szefostwa placówki do Wspólnoty. Spotykało się osoby rozumiejące i akceptujące program AA, także niechętnie nastawione, a nawet wrogo. Naszych 
luctant and even hostile. I most often directed our "graduates" to those institutions where AA meetings were held and where people familiar with the Twelve-Step program worked. Sometimes they were recovering alcoholics. However, I warned patients against combining a more or less intensive addiction psychotherapy program with working on the Steps with an AA sponsor. I compared such situations to the treatment of the same disease by two specialist doctors who do not follow the same treatment methods. The patient then has to choose one of the methods. However, in some facilities, therapists did not allow patients to participate in AA meetings, assuming that this could disrupt the process of their therapy. In my opinion, the mere participation in meetings, without working with the sponsor at the same time, does not disturb the course of the therapy process (and may even support it). Therefore, during inpatient therapy at the Dependence Treatment Centre of the Institute of Psychiatry and Neurology, participation in meetings was one of the obligatory elements of the therapeutic program. After the end of the stay, the obligation ended and the choice was solely of the patient [55].

I assume that cooperation of addiction treatment and participation in the Fellowship of Alcoholics Anonymous should be mutually complementary. I proposed (and still offer) patients the basic addiction psychotherapy program in inpatient or outpatient settings first. The patients acquire basic knowledge about oneself and one's addiction, obtaining tools to protect the patient from returning to alcohol, "dealing" with the most urgent psychological and social problems, and then consolidating and deepening the recovery process while working with a sponsor on the AA Steps. However, for people who, despite many years of contacts with Alcoholics Anonymous, are not satisfied with their emotional state, I always suggest having a professional addiction psychotherapy program or in-depth therapy, followed by the continuation of the recovery process with the sponsor within the Fellowship.

From a 40-year perspective on the mutual relations between professionals and participants of Alcoholics Anonymous, one can notice a clear dynamic from the full dependence of AA members on professionals in the initial period to rejection and reluctance to accept any kind of professional „absolwentów” kierowałem najchętniej do tych placówek, na których terenie odbywały się mityngi AA i w których pracowały osoby zaznajomione z programem Dwunastu Kroków. Czasami były to osoby zdrowiejące. Przestrzegałem jednak pacjentów przed łączeniem mniej lub bardziej intensywnego programu psychoterapii uzależnień $\mathrm{z}$ pracą nad Krokami ze sponsorem z AA. Takie sytuacje porównywałem do leczenia równolegle tej samej choroby przez dwóch lekarzy specjalistów, którzy nie hołdują tym samym metodom leczenia. Wówczas pacjent staje wobec konieczności dokonania wyboru jednej z metod. Natomiast w niektórych placówkach terapeuci zabraniali pacjentom brania udziału w spotkaniach Wspólnoty AA, wychodząc z założenia, że może to zaburzyć proces prowadzonej przez nich terapii. Moim zdaniem, samo uczestniczenie w mityngach, bez równoczesnej pracy ze sponsorem, nie zaburza przebiegu procesu terapii (a może go nawet wspierać). Dlatego też podczas stacjonarnej terapii w Ośrodku Terapii Uzależnień IPiN uczestniczenie w mityngach było jednym $\mathrm{z}$ obowiązkowych elementów programu terapeutycznego. Po zakończeniu pobytu obowiązek kończył się i wybór należał już wyłącznie do pacjenta [55].

Wychodzę z założenia, że współpraca lecznictwa uzależnień i Wspólnoty AA powinna polegać na wzajemnym uzupełnianiu się. Pacjentom proponowałem (i nadal proponuję) odbycie najpierw podstawowego programu psychoterapii uzależnień $\mathrm{w}$ warunkach stacjonarnych lub ambulatoryjnych. Zdobycie tam podstawowej wiedzy na swój temat i na temat swojego uzależnienia, uzyskanie narzędzi chroniących przed powrotem do alkoholu, „załatwienie” najpilniejszych problemów psychologicznych i społecznych, a następnie utrwalanie i pogłębianie procesu zdrowienia podczas pracy ze sponsorem nad Krokami AA. Natomiast osobom, które pomimo wieloletnich kontaktów ze Wspólnotą AA nie są zadowolone ze swojego stanu emocjonalnego, proponuję zawsze odbycie profesjonalnego programu psychoterapii uzależnień czy później tzw. terapii pogłębionej, a po nich - kontynuację procesu zdrowienia ze sponsorem w ramach Wspólnoty.

Patrząc z perspektywy 40 lat na wzajemne relacje między profesjonalistami a uczestnikami Wspólnoty AA, można zauważyć wyraźną dynamikę - od pełnej zależności członków AA od profesjonalistów w początkowym okresie, przez odrzucenie i niechęć do wszelkiego rodzaju pomo- 
help, up to gratitude and partnership. On the other hand, with professionals I have observed a change in attitude from misunderstanding, fear and negation to acceptance and focus on cooperation.

For a full picture of the relationship of the AA Fellowship with doctors and psychologists, one should also pay attention to a small point of contention that has recently appeared between professionals and some members of the AA Fellowship. This was a result of the fact that in 2016, with the recommendations of the State Agency for the Prevention of Alcohol-Related Problems, alcohol treatment facilities expanded their offer to include so called drinking reduction programs [61]. We decided to take such a step due to the fact that for many alcohol-dependent patients, immediate alcohol withdrawal, which was the basic condition for starting therapy, was completely unrealistic. Most gave up therapy and continued drinking. It turned out that the offer of patient additional treatment options gives him a sense of control over the course of treatment and thus increases the chances of staying in the therapeutic process [62].

A program to reduce drinking, proposed to alcohol dependent persons (with disorders caused by moderate or severe alcohol use according to DSM-5) [63], who at the moment are unable or do not want to stop drinking alcohol should, in my opinion, be treated as a chance for these people to look closely at their drinking, while under the watchful eye of a professional addiction therapist, and for the gradual withdrawal from alcohol [64]. In my experience, a significant proportion of participants in these programs decide, after some time and after unsuccessful attempts to limit drinking, to participate in programs focused on total abstinence. Cases of this kind are also described in the literature [65].

Those AA members who have superficially learned or misunderstood program to reduce drinking assumptions loudly protest and condemn professionals for "teaching controlled drinking", which is contrary to the idea of Alcoholics Anonymous, and especially to the idea of being "powerless over alcohol". The AA First Step says "We admitted we were powerless over alcohol - that our lives had become unmanageable" [43].

Among those who decide to try therapy are people who previously refused to try it and, which cy profesjonalnej, do wdzięczności i partnerstwa. Z kolei u profesjonalistów obserwowałem zmianę postawy od niezrozumienia, obaw i negacji, do akceptacji i nastawienia na współpracę.

Dla pełnego obrazu relacji Wspólnoty AA z lekarzami i psychologami należałoby jeszcze zwrócić uwagę na drobną „rysę”, jaka pojawiła się ostatnio na linii profesjonaliści-niektórzy członkowie Wspólnoty AA. Jej przyczyną stał się fakt, że od 2016 r., zgodnie z zaleceniami Państwowej Agencji Rozwiązywania Problemów Alkoholowych (PARPA), placówki terapii uzależnień poszerzyły swoją ofertę o tzw. programy ograniczania picia - POP [61]. Zdecydowaliśmy się na taki krok ze względu na to, że dla wielu pacjentów uzależnionych od alkoholu natychmiastowe odstawienie alkoholu, które stanowiło podstawowy warunek podjęcia terapii, było całkowicie nierealne. Większość z nich rezygnowała $z$ terapii i piła dalej. Okazało się, że zaproponowanie pacjentowi dodatkowych możliwości odbywania terapii daje mu poczucie wpływu na jej przebieg i tym samym zwiększa szanse na utrzymanie się w procesie terapeutycznym [62].

Program ograniczania picia, proponowany osobom uzależnionym od alkoholu (z zaburzeniami spowodowanymi używaniem alkoholu w stopniu umiarkowanym lub ciężkim wg DSM-5) [63], które w danym momencie nie są $\mathrm{w}$ stanie lub nie chcą odstawić alkoholu, należałoby - moim zdaniem traktować jako szansę dla tych osób na dokładne przyjrzenie się swojemu piciu, tym razem „pod okiem" profesjonalnego terapeuty uzależnień i na stopniowe odstawianie alkoholu [64]. Z moich doświadczeń wynika, że znaczna część uczestników tych programów decyduje się, po pewnym czasie i po nieudanych próbach ograniczania picia, na udział $\mathrm{w}$ programach nastawionych na całkowitą abstynencję. Takie przypadki są również opisywane w literaturze przedmiotu [65].

Ci członkowie Wspólnoty AA, którzy bardzo powierzchownie poznali założenia POP albo ich nie zrozumieli, głośno protestują i potępiają profesjonalistów za to, że „uczą kontrolowanego picia”, co jest sprzeczne z ideą Wspólnoty, a szczególnie uznawaną przez jej program „bezsilnością wobec alkoholu”. Mówi o tym Pierwszy Krok AA: „Przyznaliśmy, że jesteśmy bezsilni wobec alkoholu, że przestaliśmy kierować własnym życiem" [43].

Podejmowanie terapii przez dodatkowe osoby, a wśród nich przez te, które wcześniej nie mogły się na nią zdecydować, jest szczególnie ważne 
is of particular importance especially when most people with alcohol use disorders are not diagnosed and are not seeking treatment. Only about 20\% undergo treatment [66-70]. The treatment itself is very often seen as unattractive and stigmatizing, and alcohol use disorders are perceived by a significant part of society, including health care workers, as a moral weakness, not as a health problem [71, 72]. This is extremely important in cases of dependence in women. These adversities can be overcome only when the problems become very serious. Other American epidemiological studies show that only about $25 \%$ of alcohol dependent people ever undergo treatment, and the period from diagnosis to treatment is about 10 years [73].

Today, numerous elements of the Minnesota Model, which is geared towards full abstinence, lie at the heart of therapeutic programs in alcohol treatment facilities in Poland. The Minnesota Model has evolved over the years and currently its basic assumptions include the following:

- treating alcoholism as a disease significantly different from other mental disorders or diseases,

- treating alcoholism as a primary disease (it is not a manifestation of other disorders and alcoholism will not disappear after these have been resolved, and it does not result from any other disease, because it is a disease in itself),

- treating alcoholism as a chronically progressive, fatal and, most importantly, faultless disease caused by many different factors (polyethiology),

- treating people who suffer from this disease with respect for their personal dignity and understanding,

- the belief that the initial motivation does not determine the course and results of treatment,

- an attempt to enable a dependent person to identify with the symptoms of the disease, which can elicit the need to make changes in their life,

- recognition that one of the major symptoms of the disease is denial (one often hears that alcoholism is a disease of denial and relapse), while the existence of disease is also denied in the patient's immediate environment,

- making lifelong abstinence from all psychoactive substances a long-term goal, w sytuacji, kiedy większość osób z zaburzeniami używania alkoholu nie jest zdiagnozowanych i nie szuka leczenia, a leczenie podejmuje jedynie ok. $20 \%$ z nich [66-70]. Samo leczenie jest bardzo często traktowane jako nieatrakcyjne i stygmatyzujące, a zaburzenia używania alkoholu są postrzegane przez znaczną część społeczeństwa, w tym także przez pracowników ochrony zdrowia, jako słabość moralna, nie problem zdrowotny [71, 72]. Jest to wyjątkowo ważne w przypadkach uzależnień u kobiet. Opisane przeciwności udaje się pokonać dopiero wówczas, gdy problemy stają się bardzo poważne. $Z$ innych amerykańskich badań epidemiologicznych wynika, że jedynie ok. $25 \%$ osób uzależnionych od alkoholu podejmuje kiedykolwiek leczenie, a okres od zdiagnozowania do podjęcia leczenia wynosi ok. 10 lat [73].

Liczne elementy modelu Minnesota, który jest nastawiony na pełną abstynencję, leżą dzisiaj $\mathrm{u}$ podstaw programów terapeutycznych $\mathrm{w}$ placówkach leczących osoby uzależnione w Polsce. Model Minnesota ulegał przez lata ewolucji i aktualnie do jego podstawowych założeń należą:

- traktowanie alkoholizmu jako choroby znacząco różniącej się od innych zaburzeń czy chorób psychicznych,

- traktowanie alkoholizmu jako choroby pierwotnej (nie jest to bowiem przejaw innych zaburzeń, po których rozwiązaniu alkoholizm przestanie istnieć, jak również nie wynika on z jakiejkolwiek innej choroby, ponieważ sam w sobie jest chorobą),

- traktowanie alkoholizmu jako choroby przewlekle postępującej, śmiertelnej i co istotne niezawinionej, na której powstanie złożyło się wiele różnych czynników (polietiologia),

- traktowanie $\mathrm{z}$ należytym szacunkiem i zrozumieniem osób, które cierpią na tę chorobę oraz szanowanie ich osobistej godności,

- przekonanie, że wstępna motywacja nie decyduje o przebiegu i wynikach leczenia,

- dążenie do umożliwienia osobie uzależnionej identyfikacji z objawami choroby, co może wywołać u niej potrzebę dokonania zmian w swoim życiu,

- uznanie, że jednym z najważniejszych objawów choroby jest zaprzeczanie (często słyszy się, że alkoholizm to choroba zaprzeczeń i nawrotów), przy czym istnieniu choroby zaprzecza również najbliższe otoczenie chorego,

- stawianie jako cel długofalowy dożywotniej abstynencji od wszelkich substancji psychoaktywnych, 
- systemic approach to the disease, taking into account the active participation of close ones in the therapeutic process,

- conducting therapy through small groups - each patient is, however, treated individually, because they have their own way out of the disease and their own ways of preventing its relapse, which may threaten the abstinence of the person who is in the process of making personal changes and changes in his/her life,

- maximizing the potential of a multidisciplinary team of therapists; properly trained specialists among alcoholics or drug addicts who recover using the AA or NA program play an important role (their employment began at the Hazelden Center in 1954),

- the use of the Twelve-Step program and the philosophy of Alcoholics Anonymous in therapy as well as the systematic participation of people receiving medical treatment in AA meetings [1: 180].

Classic treatment programs based on the Minnesota Model include detoxification; evaluation of the mind; group meetings (because 80 to 90 percent of classes take place in group conditions); educational lectures and finally referral to appropriate services to continue the recovery process. These programs, conducted in inpatient centers and functioning according to the principles of the TSF model (Twelve Steps Facilitation), facilitate the use of the AA Twelve-Step program, are very intense and tend to cause a rapid change in the patient's life within a very short time (28 days). The assumed goals of treatment are recognition and acceptance of powerless over alcohol, as well as recognition of the need for change and help in immediately commencing changes in lifestyle and functioning, which is associated with "carrying" the patient through the first 3-5 Steps [47].

\section{- RESEARCH ON}

\section{THE EFFECTIVENESS OF The TWelve-Step Program}

Research on the effectiveness of Alcoholics Anonymous Fellowship activity and the mechanisms of behavior change (MOBC) during the implementation of the program suggest that Alcoholics Anonymous provides effective support in reducing public health problems. The re-
- systemowe podejście do choroby, uwzględniające jednocześnie aktywny udział w procesie terapeutycznym osób najbliższych,

- prowadzenie terapii przez małe grupy - każdy pacjent jest jednak traktowany indywidualnie, ma bowiem ustaloną własną drogę wychodzenia $\mathrm{z}$ choroby oraz własne sposoby zapobiegania jej nawrotowi, który może grozić przerwaniem abstynencji przez osobę będącą w trakcie dokonywania zmiany osobistej i zmian w swoim życiu,

- maksymalne wykorzystanie potencjału wielodyscyplinarnego zespołu terapeutów; istotną rolę odgrywają w nim odpowiednio przeszkoleni specjaliści spośród alkoholików bądź narkomanów, którzy zdrowieją, korzystając z programu AA lub NA (ich zatrudnianie rozpoczęto w Ośrodku Hazelden w 1954 r.),

- wykorzystywanie w terapii programu Dwunastu Kroków i filozofii AA oraz systematyczny udział osób leczących się $\mathrm{w}$ spotkaniach Wspólnoty AA [1: 180].

Klasyczne programy leczenia, których podstawę stanowi Model Minnesota, obejmują: detoksykację, ocenę stanu psychicznego, spotkania grupowe (ponieważ 80-90\% zajęć odbywa się w warunkach grupowych), edukację/wykłady, a na koniec skierowanie do odpowiednich usług $\mathrm{w}$ celu kontynuowania procesu zdrowienia. Programy te, prowadzone w stacjonarnych ośrodkach funkcjonujących wg zasad tego modelu (TSF), ułatwiają korzystanie z programu Dwunastu Kroków AA, są bardzo intensywne i zmierzają w kierunku wywołania gwałtownej zmiany w życiu pacjenta w ciągu bardzo krótkiego czasu (28 dni). Zakładane cele leczenia to uznanie i akceptacja bezsilności wobec alkoholu, a także uznanie potrzeby zmiany i pomocy $\mathrm{w}$ natychmiastowym przystąpieniu do dokonywania zmian w stylu życia i sposobie funkcjonowania, co wiąże się z "przeprowadzeniem” pacjenta przez pierwsze 3-5 Kroków [47].

\section{- BADANIA NAD SKUTECZNOŚCIĄ PROGRAMU DWUNASTU KROKÓW}

Badania nad skutecznością działania Wspólnoty AA oraz nad mechanizmami powodującymi wystąpienie zmian w zachowaniu (MOBC) w trakcie realizacji programu oceniają Wspólnotę jako skutecznego sprzymierzeńca $\mathrm{w}$ ograniczaniu problemów dotyczących zdrowia publicznego. W badaniach podkreśla się też, że przebieg zmian zachodzących 
search also emphasizes that the changes taking place during the Twelve-Step program process is very similar to those during psychotherapy. Thus, the program applies psychological methods to remove the symptoms of the disorder and obtains beneficial changes in the state of health and behavior, without taking the person away from their environment and incurring financial costs $[74,75]$. Studies show that abstinence rates are twice as high for those who decide to attend AA meetings, and a higher frequency of attendance has a positive effect on maintaining abstinence [76]. Similar conclusions can be drawn from subsequent studies conducted on a group of 150 hospitalized patients. They showed that frequent participants at Alcoholics Anonymous meetings (before, during and after treatment) not only significantly reduced alcohol consumption but also reported fewer psychological problems and significantly improved quality of life, compared to people who did not participate in AA meetings [77].

Studies of a group of 495 AA members treated in public and private facilities show that working with a sponsor benefits the recovery process and sustained abstinence [78]. Other researchers point out the beneficial effects of participation in AA on reducing short- and long-term alcohol consumption as well as the important role of group consistency and dynamics, and of having a sponsor in the recovery process in the AA Fellowship [79, 80]. In an eight-year observation of 466 persons ( $51 \%$ men) divided into 4 groups (no treatment, only AA, only treatment, and treatment plus AA) showed that those who had no treatment functioned the worst. Participation in AA or in therapy in the first year of observation was associated with maintaining abstinence by a larger percentage of persons tested after 8 years [81]. Swedish research suggests that a "membership of self-help groups" has a beneficial effect on the maintaining abstinence of those participated in AA Twelve-Step program therapy [82]. There is much research which links long-term abstinence with the participation in AA meetings and working with a sponsor [83-87]. However, it should be remembered that the AA Twelve-Step program speaks of being "powerless over alcohol" and therefore recommends lifelong abstinence. Therefore, when assessing its effectiveness, researchers place the main emphasis on measuring the length w trakcie realizacji programu Dwunastu Kroków jest bardzo zbliżony do zmian, jakie zachodzą podczas procesu psychoterapii. Podobnie jak ma to miejsce $\mathrm{w}$ psychoterapii, program umożliwia usunięcie środkami psychologicznymi objawów choroby oraz uzyskanie korzystnych zmian w stanie zdrowia i zachowaniu, bez odrywania danej osoby od jej środowiska i bez ponoszenia kosztów finansowych [74, 75]. Jak wynika z badań, wskaźniki utrzymywania abstynencji są dwukrotnie wyższe u tych osób, które decydują się uczęszczać na spotkania AA, a większa częstotliwość uczęszczania wpływa korzystnie na utrzymywanie abstynencji [76]. Podobne wnioski płyną z kolejnych badań przeprowadzonych na grupie 150 hospitalizowanych pacjentów. Wykazały one, że osoby często uczęszczające na spotkania AA (przed, w trakcie i po zakończeniu leczenia), w porównaniu z osobami, które nie brały udziału w spotkaniach AA, nie tylko istotnie ograniczyły picie alkoholu, ale również miały mniej problemów psychologicznych i znacząco poprawiły jakość swojego życia [77].

Z badań grupy 495 członków Wspólnoty AA, którzy leczyli się w placówkach publicznych i prywatnych, wynika, że korzystnie na utrzymywanie abstynencji oraz na przebieg procesu zdrowienia wpływa praca ze sponsorem [78]. Inni badacze zwracają uwagę na korzystny wpływ uczestnictwa w AA na krótko- i długoterminowe zmniejszenie spożycia alkoholu, a także na ważną rolę spójności i dynamiki grupowej oraz posiadania sponsora w procesie odzyskiwania zdrowia we Wspólnocie AA $[79,80]$. Z kolei ośmioletnia obserwacja 466 osób (51\% mężczyzn) podzielonych na 4 grupy (nieleczeni, tylko AA, tylko leczenie i leczenie plus AA) wykazała, że najgorzej funkcjonowały osoby nieleczone. Udział w AA lub odbycie terapii $\mathrm{w}$ pierwszym roku obserwacji wiązały się z utrzymywaniem abstynencji po 8 latach przez większy odsetek badanych [81]. Szwedzkie badania sugerują, że korzystny wpływ na utrzymywanie abstynencji przez osoby, które odbyły terapię w programie Dwunastu Kroków AA, ma „przynależność do grup wzajemnej pomocy" [82]. Jest jeszcze wiele innych badań, które łączą wieloletnie utrzymywanie abstynencji z uczestnictwem w spotkaniach AA i pracą ze sponsorem [83-87]. Należy jednak pamiętać, że program Dwunastu Kroków AA mówi o „bezsilności wobec alkoholu” i dlatego zaleca dożywotnią abstynencję. Dlatego przy ocenie jego skuteczności badacze kładą głównie nacisk 
of abstinence, often leaving out other important factors in the recovery process.

Researchers pay attention to one more aspect and emphasize that in times of such prevalence of alcohol-related problems, victims often face much stigmatization and discrimination and at the same time the availability of treatment leaves much to be desired. Therefore, the possibility of recovery in AA is a much needed and convenient form of help and good support for professional treatment [88].

According to the aforementioned Prof. Vaillant, four factors determine the effectiveness of AA in relapse prevention: external supervision (the important role of a sponsor and the AA group), new and competitive behavior against dependence (substitute dependency), new caring relationships and increased spirituality. $\mathrm{He}$ argues that "like methadone in opiate addiction, the positive emotions induced by AA provide a safe, nonpharmacological substitute for alcohol" [89]. He also emphasized the important role of behavioral-cognitive therapy in preventing relapses, while at the same time he believed that "the skepticism of some professionals regarding AA (...) would appear to be unwarranted. Alcoholics Anonymous is probably without serious side effects" [90].

A special award for the Fellowship of Alcoholics Anonymous came from the $10^{\text {th }}$ US Congressional Report recommendation which states that "professional treatment based on the 12-steps approaches can be as effective as other therapeutic approaches and may actually achieve more sustained abstinence" [91: 448]. Twenty years later, an analysis of 27 studies within Cochrane Library, with 10,565 participants, showed that therapy consisting of encouraging participation in AA and becoming familiar with the Twelve-Step Facilitation program (TSF) delivers higher rates of persistent abstinence and reduces the negative consequences of drinking alcohol, especially in the long term (up to 3 years), compared to other evidence-based treatments, including cognitive behavioral therapy (CBT) and motivational enhancement therapy (MET). At the same time, health care costs are significantly reduced [92-94].

While there is no doubt that this approach has had much success, both AA itself and the AA Fellowship-based approach to therapy have also been criticized. As demonstrated by na pomiar długości abstynencji, pomijając często inne, ważne dla procesu zdrowienia czynniki.

Badacze zwracają uwagę na jeszcze jeden aspekt i podkreślają, że w czasach kiedy problemy alkoholowe są tak bardzo rozpowszechnione, osoby $\mathrm{z}$ tymi problemami często piętnowane i dyskryminowane, a jednocześnie dostępność do leczenia pozostawia wiele do życzenia - to możliwość zdrowienia przez AA jest bardzo potrzebną i wygodną formą pomocy oraz dobrym wsparciem dla profesjonalnego lecznictwa [88].

Zdaniem wspomnianego już wcześniej prof. Vaillanta, na skuteczność AA w zapobieganiu nawrotom wpływają cztery czynniki, tj. zewnętrzny nadzór (ważna rola sponsora i grupy AA), nowe i konkurencyjne wobec uzależnienia zachowania (substytuty uzależnienia), związki oparte na trosce o innych, a także rozwinięta duchowość. Twierdzi on, że „pozytywne emocje wywoływane przez AA stanowia bezpieczny, niefarmakologiczny substytut alkoholu, podobnie jak metadon w uzależnieniu od opiatów" [89]. Podkreśla też ważną rolę terapii behawioralno-poznawczej w zapobieganiu nawrotom, a jednocześnie uważa, że „sceptycyzm niektórych profesjonalistów dotyczący AA (...) wydaje się nieuzasadniony. Anonimowi Alkoholicy prawdopodobnie nie wywołują groźnych efektów ubocznych" [90].

Szczególnym wyróżnieniem dla Wspólnoty AA była rekomendacja zawarta w 10. Raporcie dla Kongresu Stanów Zjednoczonych, mówiąca o tym, że „profesjonalne leczenie bazujące na programie Dwunastu Kroków może być równie skuteczne jak inne podejścia terapeutyczne i prowadzić do uzyskania bardziej trwałej abstynencji” [91: 448]. Przeprowadzona 20 lat po tym raporcie, $w$ ramach Biblioteki Cochrane’a, analiza 27 badań z udziałem 10565 uczestników wykazała, że terapia polegająca na zachęcaniu do uczestnictwa w AA i zaznajamianiu się z programem Dwunastu Kroków (TSF) daje wyższe wskaźniki trwałej abstynencji i ogranicza negatywne konsekwencje picia alkoholu, szczególnie $\mathrm{w}$ dłuższym okresie (do 3 lat), w porównaniu $\mathrm{z}$ innymi metodami leczenia opartymi na dowodach, w tym $\mathrm{z}$ terapią poznawczo-behawioralną (CBT) i motywacyjną terapią wspomagającą (MET). Jednocześnie w sposób istotny zmniejszają koszty opieki zdrowotnej [92-94].

Chociaż zarówno sama Wspólnota AA, jak i oparte na jej założeniach podejście do terapii spotyka się z krytyką, nie ulega wątpliwości, że takie podejście ma liczne sukcesy. Jak wykazał przegląd 
the review of randomized studies from 1999, the AA program is no better than alternatives to it, and membership in AA can have negative effects. At the same time, the authors of this review stated that many of the studies included were methodologically incorrect [95]. However, the aforementioned research, published as part of the Cochrane Library, suggests that membership in AA is beneficial [93] and that there is no need for anyone to defend AA because the Fellowship "will defend itself" [96].

The researchers emphasize that the alcohol dependent individuals, who also learn the AA program in therapy, after completing therapy receive support in the recovery process that including attitude changes, freedom from guilt about the past and finding a new way of life. There are studies showing that thanks to the AA program, about $2 / 3$ of patients achieve "a good result one year after discharge from hospital" [97]. According to a follow-up study of a group of 1083 men and women treated in addiction facility at the Hazelden Foundation, $53 \%$ of the subjects maintained abstinence for a year after leaving hospital [98]. In turn, Danish researchers found that patients who underwent therapy in the Minnesota Model remained abstinent for longer time compared to the control group [99]. One recent study, based on a 6-month follow-up of participants in 24-hour therapy, claimed "a Minnesota-based treatment programme to be effective in helping people with alcohol dependence to reduce the amount of alcohol they consume and sustain this reduction beyond the treatment period" [100]. The follow-up study covered 245 drug dependent persons aged 12-18 divided into those who 1. completed treatment according to the Minnesota Model, 2. started such treatment but did not complete it, and 3 . were on the waiting list. After 12 months, positive results were seen in $53 \%$ of those who completed the therapy program, and only in $15 \%$ of those who did not complete the treatment, and in $28 \%$ of those in the waiting group. Interestingly, during the follow-up period, the subjects mostly consumed alcohol, although they most often used marijuana before starting treatment [101].

\section{- Discussion}

This outline of the history of the AA movement around the world and in Poland presented in this randomizowanych badań z 1999 r., program AA nie jest lepszy niż alternatywne wobec niego działania, a członkostwo w AA może nawet powodować negatywne skutki. Jednocześnie autorzy tego przeglądu stwierdzili, że wiele z uwzględnionych w nim badań było niepoprawnych metodologicznie [95]. Natomiast wspomniane już badania, opublikowane w ramach Biblioteki Cochrane’a, sugerują, że członkostwo w AA jest jednak korzystne [93] i że nie ma potrzeby, aby ktokolwiek występował $\mathrm{w}$ obronie AA, bo Wspólnota „obroni się sama” [96].

Badacze podkreślają, że osoby uzależnione od alkoholu, które podczas terapii poznają również program AA, po ukończeniu terapii uzyskują wsparcie $\mathrm{w}$ procesie zdrowienia, m.in. przez dokonywanie sugerowanych $\mathrm{w}$ programie zmian $\mathrm{w}$ swoich postawach, uwolnienie się od poczucia winy z przeszłości, znalezienie nowego sposobu na życie. Są badania wykazujące, że dzięki programowi AA nawet $2 / 3$ pacjentów osiąga „dobry wynik po upływie roku od czasu wypisania ze szpitala” [97]. Jak wynika z badań grupy 1083 mężczyzn i kobiet leczonych w ośrodku Hazelden Foundation, 53\% badanych utrzymywało abstynencję przez okres roku od czasu wyjścia ze szpitala [98]. Z kolei duńscy badacze ustalili, że pacjenci, którzy odbyli terapię w modelu Minnesota, w porównaniu z grupą kontrolną, dłużej zachowywali abstynencję [99]. Jedno z ostatnich badań, przeprowadzonych na podstawie 6-miesięcznej obserwacji osób uczestniczących w całodobowej terapii, wykazało, że „program leczenia oparty na modelu Minnesota może skutecznie pomagać osobom uzależnionym od alkoholu w zmniejszaniu ilości spożywanego alkoholu i utrzymywaniu tej redukcji po okresie leczenia" [100]. Badaniami objęto 245 osób uzależnionych od narkotyków w wieku 12-18 lat, podzielonych na trzy grupy, tj. tych, którzy 1) ukończyli leczenie wg modelu Minnesota, 2) podjęli takie leczenie, ale go nie ukończyli i 3) znaleźli się na liście oczekujących. Po upływie 12 miesięcy pozytywne wyniki zaobserwowano u 53\% osób, które ukończyły program terapii, a jedynie u $15 \%$ osób, które leczenia nie ukończyły, i u $28 \%$ osób z grupy oczekujących. Ciekawy może być fakt, że w okresie obserwacji badani najczęściej spożywali alkohol, chociaż przed podjęciem leczenia najczęściej korzystali z marihuany [101].

\section{- OMÓWIENIE}

Przedstawiony $\mathrm{w}$ tym artykule zarys historii ruchu AA na świecie i w Polsce - oraz refleksje na 
article, and reflections on its development, the people using the program and therapeutic approaches etc. is not intended to be a professional historical analysis. It is an attempt to look at this movement from the perspective of a person involved in its development for decades. I have supported and accompanied the Fellowship of Alcoholics Anonymous in Poland over the years and at the same time I have gained experience and learned from its members coming to understand the alcoholic and his or her illness. I have also tried to involve AA members in supporting institutional forms of treatment for dependent persons.

The history of the Fellowship shows that on the one hand the AA movement was autonomous and that it responded to the needs of millions of people suffering from drinking alcohol, but on the other hand it was dependent on specific social determinants. Although its initiators were often charismatic individuals, AA could not grow so dynamically without favorable circumstances. It is no accident that the AA movement was born in the United States at a time when the project of sobering up by the use of prohibition had failed. The new definition of the problem, the sources of which were no longer in the devil drink, but in the individual, responded to society's demand as it rejected prohibition and was no longer willing to accept the current policy of controlling alcohol. Moreover, according to AA ideology, the alcoholic could no longer be condemned as an immoral individual, because the problem lay not in moral structure, but in the elusive factors that making one person more susceptible to illness than another.

It is no accident that the AA movement become noticed in Poland during the political thaw in the second half of the 1950s, when many modern solutions were adopted in social policy. It was not until 1980 when the Solidarity movement initiated an open debate on many social problems, including alcoholism, that AA groups emerged on a larger scale. The unprecedented elsewhere development of AA in Poland and implementation of the Twelve Steps principles in medical care took place during the neoliberal systemic transformations in the nineties. At that time, the alcohol monopoly and control policy were rejected as a "remnant of socialism".

Although we do not have accurate data on the number of AA Fellowship members in Poland, it can be assumed that the majority of people who temat jego rozwoju, osób korzystających z progra$\mathrm{mu}$, podejść terapeutycznych itp. - nie ma ambicji bycia profesjonalną analizą historyczną. Jest próbą spojrzenia na ten ruch $\mathrm{z}$ perspektywy osoby zaangażowanej przez dziesięciolecia w jego rozwój. Przez lata towarzyszenia Wspólnocie AA w Polsce wspierałem ją, ale jednocześnie zdobywałem doświadczenie i uczyłem się od jej członków rozumienia alkoholika i jego choroby. Równocześnie starałem się angażować członków Wspólnoty do wspierania instytucjonalnych form leczenia osób uzależnionych.

Historia Wspólnoty pokazuje, że z jednej strony ruch AA miał charakter autonomiczny, odpowiadał na potrzeby milionów osób cierpiących z powodu picia alkoholu, $\mathrm{z}$ drugiej jednak strony był zależny od konkretnych uwarunkowań społecznych. Mimo że jego inicjatorami były często charyzmatyczne jednostki, to jednak nie mógłby się rozwijać tak dynamicznie bez sprzyjających okoliczności. Nie przypadkiem ruch AA narodził się w Stanach Zjednoczonych w czasie, kiedy fiaskiem zakończył się projekt otrzeźwienia przez prohibicję. Nowa definicja problemu, którego źródła nie tkwiły już w diabelskim napoju, ale w jednostce, odpowiadała na zapotrzebowanie społeczeństwa - odrzuciło ono prohibicję i nie było skłonne akceptować dłużej dotychczasowej polityki kontroli nad alkoholem. Co więcej, w myśl ideologii AA, alkoholik nie mógł być już potępiany jako jednostka niemoralna, jego problem tkwił bowiem nie w jego konstrukcji moralnej, ale w nieuchwytnych wówczas czynnikach, powodujących, że był bardziej niż inni podatny na chorobę.

Nie przypadkiem też o ruchu AA zaczęto mówić w Polsce w czasie odwilży politycznej, w drugiej połowie lat 50., kiedy w polityce społecznej przyjęto wiele nowoczesnych, jak na tamte czasy, rozwiązań. Grupy AA pojawiły się na szerszą skalę po upływie dziesiątków lat, dopiero w 1980 r., roku wybuchu ruchu Solidarność, który zainicjował otwartą debatę publiczną na temat wielu problemów społecznych, w tym alkoholizmu. Niespotykany gdzie indziej rozwój AA w Polsce i implementacja zasad Dwunastu Kroków w lecznictwie nastąpiły w czasie neoliberalnych transformacji ustrojowych w latach 90. W tym właśnie czasie monopol alkoholowy i polityka kontroli nad alkoholem zostały odrzucone jako „przeżytek socjalizmu”.

Mimo że nie mamy dokładnych danych o liczebności członków wspólnoty AA w Polsce, moż- 
could benefit from participation are not included. It seems that there is a need for reflection on this topic and more options for people who are not able to accept abstinence as a treatment goal (one of the possibilities are the abovementioned drinking reduction programs). There is also a lack of research on factors favoring participation in Alcoholics Anonymous Fellowship, and especially on factors discouraging participation in the AA movement.

The results of research on the effectiveness of treatment to date confirm that the model using the AA Twelve-Step program is similarly effective to models using cognitive behavioral therapy (CBT) or motivational dialogue [102]. A recent analysis of 27 studies from the Cochrane Library showed, however, that using AA-related therapy programs provides a higher percentage of abstinence days than for cognitive behavioral therapy [93, 94]. This longer abstinence can be associated with participation in AA meetings after the end of the therapeutic program and with the awareness that the person is "powerless over alcohol" on which Alcoholics Anonymous Fellowship places so much emphasis.

A study on the effectiveness of treatment in 1996 at the Dependence Therapy Centre (OTU) of the Institute of Psychiatry and Neurology, where we placed a strong emphasis on familiarizing patients with the Twelve-Step program, showed that at least $36 \%$ of respondents remained abstinent for a period of 12 months. At the same time, $66 \%$ reported an improvement in health, $76 \%$ improved relations with relatives, and $69 \%$ improvement in work situation [103]. A few years later, I conducted a study among former patients of the same center on "The impact of the basic therapeutic program on the subjective assessment of alcohol dependent patients' the quality of life" (IPiN: topic no. 34/2003, unpublished study). According to the study, one year after the end of treatment, maintaining abstinence was positively correlated with participation in AA meetings. At the same time, $40 \%$ of respondents reported an improvement in their material situation, $66 \%$ subjectively felt their health had improved, and 72\% reported improved relationships with relatives (to a significant extent in $40 \%$ of the respondents). On the other hand, those who returned to drinking did so less often than before their therapy (74\%) and their binges were shorter (77\%) because they na założyć, że nie obejmuje ona większości ludzi, którzy mogliby być jej uczestnikami i beneficjentami. Wydaje się, że potrzebna jest refleksja na ten temat i szersza oferta dla osób, które nie są w stanie zaakceptować abstynencji jako celu leczenia (jedną z możliwości są wspomniane programy ograniczania picia - POP). Brakuje też badań nad czynnikami sprzyjającymi przystąpieniu do Wspólnoty AA, a zwłaszcza nad czynnikami zniechęcającymi do udziału w ruchu AA.

Dotychczasowe wyniki badań na temat efektywności leczenia potwierdzają, że model wykorzystujący program Dwunastu Kroków AA jest w podobny sposób skuteczny jak modele wykorzystujące terapię behawioralno-poznawczą (CBT) czy też dialog motywujący [102]. Przeprowadzona ostatnio analiza 27 badań z Biblioteki Cochrane’a wykazała jednak, że korzystanie z programów terapii związanych z AA daje większy odsetek dni abstynencji niż w przypadku terapii behawioralno-poznawczej $[93,94]$. Tę dłuższą abstynencję można powiązać $\mathrm{z}$ uczestniczeniem $\mathrm{w}$ mityngach AA po zakończeniu programu terapeutycznego oraz ze świadomością „bezsilności wobec alkoholu”, na którą tak duży nacisk kładzie Wspólnota AA.

Badanie skuteczności leczenia w Ośrodku Terapii Uzależnień (OTU) IPiN w 1996 r., gdzie duży nacisk kładliśmy na zapoznawanie pacjentów $\mathrm{z}$ programem Dwunastu Kroków, wykazało 12-miesięczną abstynencję u co najmniej $36 \%$ badanych. Jednocześnie poprawę stanu zdrowia relacjonowało $66 \%$, poprawę stosunków z bliski$\mathrm{mi}-76 \%$, a poprawę sytuacji w pracy $-69 \%$ badanych [103]. Kilka lat później przeprowadziłem wśród byłych pacjentów tego samego ośrodka badanie nt. „Wpływ podstawowego programu terapeutycznego na subiektywną ocenę jakości życia pacjentów uzależnionych od alkoholu" (IPiN: temat nr 34/2003, badanie nieopublikowane). Jak wynikało z badania, po upływie roku od zakończenia leczenia utrzymywanie abstynencji korelowało pozytywnie $\mathrm{z}$ uczestniczeniem $\mathrm{w}$ mityngach AA. Jednocześnie u $40 \%$ badanych poprawiła się sytuacja materialna, u $66 \%$ poprawił się subiektywnie odczuwany stan zdrowia, a u $72 \%$ uległy poprawie relacje z bliskimi (u 40\% w stopniu znacznym). Z kolei osoby, które powróciły do picia, piły rzadziej niż przed terapią (74\%), ich „ciągi” były krótsze (77\%), bo wcześniej niż przed leczeniem poszukiwały pomocy [104]. Inne nasze badania dotyczące skuteczności podstawowego programu 
sought help much earlier than they did before treatment [104]. Other studies we conducted on the effectiveness of the basic dependence psychotherapy program at OTU showed statistically significant improvement in all analyzed areas including a significant increase in the sense of coherence and its components (senses of comprehensibility, controllability and sensibility), a significant reduction in the severity of symptoms in all scales studied (the severity of depressive symptoms was relatively most reduced) and there were significant changes in coping strategies [105].

At this point, it is worth quoting an interesting definition of mental health recovery proposed by William Anthony, a psychiatrist and director of the Psychiatric Rehabilitation Center in Boston: "Recovery is a deeply personal, unique process of changing one's attitudes, values, feelings, goals, skills and/or roles. It is a way of living a satisfying, hopeful and contributing life even with limitations caused by the illness. Recovery involves the development of new meaning and purpose in one's life as one grows beyond the catastrophic effects of mental illness" [106].

Abstinence maintenance alone, which underlies the AA Twelve-Step program principle of being "powerless over alcohol" and recommending lifelong abstinence, should not be the only factor taken into account when assessing the effectiveness of treatment and recovery. Obtaining a fairly objective picture of treatment effectiveness is only possible when factors such as the general physical and mental condition of the treated person, their family and professional functioning, material stability as well as changing the way of drinking after treatment are also taken into account (e.g. the frequency of drinking, the number of days with and without alcohol, the amount of alcohol consumed, the length of binges as well as the associated time after these binges in which the drinker begins to seek help). Some researchers emphasize that maintaining abstinence does not have to go hand in hand with improving social functioning, i.e. working more regularly, limiting contacts with their current community or acquaintances, limiting or ceasing aggressive behavior in relation to their environment, joining in affairs at home and providing assistance in supporting the family, limiting or giving up illegal activities, as well as greater care for one's own health, external appearance or housing conditions $[107,108]$. psychoterapii uzależnień w OTU wykazały u badanych istotną statystycznie poprawę we wszystkich analizowanych zakresach: istotny wzrost poczucia koherencji i jego składowych, tj. poczucia zrozumiałości, sterowalności i sensowności, istotne zmniejszenie nasilenia objawów we wszystkich badanych skalach (stosunkowo najbardziej obniżyło się nasilenie objawów depresyjnych) oraz istotne zmiany strategii radzenia sobie ze stresem [105].

W tym miejscu warto jeszcze przytoczyć interesującą definicję odzyskiwania zdrowia psychicznego zaproponowaną przez Williama Anthony'ego, psychiatrę i dyrektora Centrum Rehabilitacji Psychiatrycznej w Bostonie: „Zdrowienie jest głęboko osobistym, wyjątkowym procesem zmiany postaw, wartości, uczuć, celów, umiejętności lub ról. Jest to sposób na prowadzenie życia satysfakcjonującego, pełnego nadziei i sensu, pomimo ograniczeń powodowanych przez chorobę. Proces zdrowienia obejmuje kształtowanie nowych znaczeń i celów życiowych, w miarę wychodzenia poza katastrofalne konsekwencje choroby psychicznej" [106].

Samo utrzymywanie abstynencji, które leży u podstaw programu Dwunastu Kroków AA, mówiącego o „bezsilności wobec alkoholu” i zalecającego dożywotnią abstynencję, nie powinno być jedynym czynnikiem uwzględnianym podczas oceny skuteczności leczenia i przebiegu procesu zdrowienia. Uzyskanie w miarę obiektywnego obrazu skuteczności leczenia możliwe jest dopiero wówczas, kiedy zostaną wzięte pod uwagę również takie czynniki, jak: ogólna kondycja fizyczna i psychiczna osoby leczonej, jej funkcjonowanie rodzinne i zawodowe, stabilizacja materialna, a także zmiana sposobu picia po leczeniu (np. częstotliwość picia, liczba dni z alkoholem i bez, ilości wypijanego alkoholu, długość „ciągów” oraz związany $\mathrm{z}$ tym czas, po jakim osoba pijąca zaczyna poszukiwać pomocy). Część badaczy podkreśla, że utrzymywanie abstynencji nie musi iść $\mathrm{w}$ parze z poprawą funkcjonowania społecznego, czyli m.in. z bardziej regularną pracą, ograniczeniem kontaktów $\mathrm{z}$ dotychczasowym środowiskiem, ograniczeniem lub zaprzestaniem agresywnych zachowań w stosunku do otoczenia, włączeniem się $\mathrm{w}$ sprawy domowe i udzielaniem pomocy w utrzymywaniu rodziny, ograniczeniem lub rezygnacją z działań sprzecznych z prawem, a także większą dbałością o stan własnego zdrowia, swój wygląd zewnętrzny czy o warunki mieszkaniowe $[107,108]$. 
However, comparing studies on the effectiveness of treating alcohol dependent persons is extremely difficult because the study groups differ in many respects. This includes the health of group members, severity of symptoms and duration of dependence, motivation for treatment, and existing therapeutic experience. There are also different ways of implementing therapy programs and differing competencies of those implementing these programs.

From the practitioner's point of view, however, it is not the most important thing that, for example, $2 / 3$ of patients received a "good result", more than half maintained abstinence, and others maintained abstinence longer than the control group, but the fact that the AA program has helped many people recover from alcohol dependence, and has reduced their consumption in others, which must have had a positive effect on their health. It is also important that the Twelve-Step program of Alcoholics Anonymous and treatment programs that take into account AA Fellowship assumptions are beneficial for the recovery process of thousands of alcohol dependent people. Thanks to this program, they gain support in maintaining abstinence, just like thousands more do thanks to abstinence clubs or sobriety organizations, religious or church institutions, or due to the periodic adoption of pharmacological agents. It should be emphasized that the amount of time one can participate in Alcoholics Anonymous Fellowship is not limited and one can receive support for the rest of one's life. The choice of the method of recovery, however, always depends on the person who has the alcohol problem. In turn, every individual who has been saved is important to a doctor or therapist.

Although AA Fellowship, according to Tenth Tradition "has no opinion on outside issues", its impact on public life turned out to be significant because:

- of the spread of AA ideas: the American Medical Association has granted alcoholism the status of a disease,

- many therapeutic programs use the Twelve-Step program, and recommend that their patients participate in "twelve-step" self-help groups (e.g. AA, NA, AH),

- those convicted for drinking and driving offences are ordered to attend AA meetings,

- recovering alcoholics who participate in Alcoholics Anonymous Fellowship are employed in the implementation of therapeutic programs,
Porównywanie badań na temat efektywności leczenia osób uzależnionych od alkoholu jest jednak niezwykle trudne, ponieważ badane grupy różnią się między sobą pod wieloma względami. Dotyczy to m.in. stanu zdrowia członków grupy, nasilenia objawów i czasu trwania uzależnienia, motywacji do leczenia, dotychczasowych doświadczeń terapeutycznych. Różne są także sposoby realizacji programów terapii oraz kompetencje osób realizujących te programy.

Z punktu widzenia lekarza-praktyka nie jest jednak najważniejsze to, że „dobry wynik” uzyskało na przykład 2/3 leczonych, ponad połowa utrzymywała abstynencję, a inni utrzymywali abstynencję dłużej niż osoby z grupy kontrolnej, lecz sam fakt, że program AA pomógł wielu osobom w zdrowieniu $\mathrm{z}$ uzależnienia od alkoholu, a u innych spowodował ograniczenie spożycia, co musiało wpłynąć korzystnie na ich stan zdrowia. Istotne jest też to, że program Dwunastu Kroków Wspólnoty AA i programy terapeutyczne uwzględniające założenia Wspólnoty są korzystne dla procesu zdrowienia tysięcy osób uzależnionych od alkoholu. Dzięki niemu uzyskują oni wsparcie w utrzymywaniu abstynencji, podobnie jak kolejne tysiące dzięki klubom abstynenta czy organizacjom trzeźwościowym, instytucjom religijnym bądź kościelnym lub dzięki okresowemu przyjmowaniu środków farmakologicznych. Warto tu jednak podkreślić, że czas uczestniczenia we Wspólnocie AA nie jest limitowany i można otrzymywać od niej wsparcie do końca życia. Wybór metody zdrowienia zależy jednak zawsze od samej osoby, która ma problem alkoholowy. Dla lekarza czy terapeuty ważna jest $\mathrm{z}$ kolei każda uratowana jednostka.

Chociaż Wspólnota AA, zgodnie z Dziesiątą Tradycją „nie zajmuje stanowiska wobec problemów spoza Wspólnoty”, to jej wpływ na życie publiczne okazał się istotny, gdyż:

- dzięki rozpowszechnieniu idei AA Amerykańskie Towarzystwo Medyczne przyznało alkoholizmowi status choroby,

- wiele programów terapeutycznych wykorzystuje program Dwunastu Kroków, a swoim pacjentom zaleca udział w „dwunastokrokowych” grupach samopomocowych (np. AA, NA, AH),

- skazani sądownie za jazdę po alkoholu mają nakaz uczestniczenia w spotkaniach AA,

- przy realizacji programów terapeutycznych zatrudnia się alkoholików zdrowiejących poprzez Wspólnotę AA, 
- specialist training programs include knowledge of the Twelve-Step program,

- many other self-help groups have been formed that include the Twelve-Step program [1:286-287].

The world-famous American writer and publicist, Kurt Vonnegut asked "What has been America's most nurturing contribution to the culture of this planet so far? Many would say Jazz. I, who love jazz, will say this instead: Alcoholics Anonymous" [109]. In his opinion it is important that America gave the world "the idea of Alcoholics Anonymous because it provided people with a new family which would care for them" [110].

In conclusion, I would like to quote the words of William R. Miller - a co-creator of the motivational dialogue method and an outstanding researcher, winner of the 1994 Jellinek Memorial Awards, professor of psychology and psychiatry at the University of New Mexico in Albuquerque. After dealing with addiction for 40 years, he said: "I will never understand alcoholism or the essence of AA from the inside, but over time I began to appreciate the depth and scope of this movement with great gratitude - a community which is undeterred in its attempt to help tormented people with their suffering. In this sense, I made friends with Bill W." [111:272].

I must add that I find great satisfaction in that, by directing my dependent patients to the Fellowship of Alcoholics Anonymous, I could, as a doctor, provided effective help to many sick and suffering people. Many of them, thanks to therapy and later the continuation of recovery through the Twelve-Step program, have become healthier than before their illness, and this is extremely rare in medicine.

\section{- Conclusions}

There is no doubt that both doctors (especially psychiatrists) and psychologists have significantly contributed to the creation and development of the Alcoholics Anonymous Fellowship around the world and in Poland. Numerous studies show that this has borne fruit as significant support from the AA Fellowship for the treatment of people dependent on alcohol and/or other psychoactive substances as well as for the treatment of those suffering from other mental health problems. Participation in Alcoholics Anonymous should be treated as a good form of coping with alcohol use
- programy szkolenia specjalistów uwzględniają znajomość programu Dwunastu Kroków,

- powstało wiele innych grup samopomocowych uwzględniających program Dwunastu Kroków [1: 286-287].

Światowej sławy amerykański pisarz i publicysta, Kurt Vonnegut, zadał pytanie „Jaki był największy wkład Ameryki do kultury tej planety? Wielu powiedziałoby Jazz. Ja, który kocham jazz, zamiast tego powiem: Anonimowi Alkoholicy" [109]. Bardzo ważne jest, jego zdaniem, że Ameryka dała światu ideę „Anonimowych Alkoholików, bo adepci AA znajdują nową rodzinę, która bierze ich w opiekę" [110].

Na zakończenie chciałbym jeszcze przytoczyć bliskie mi słowa Williama R. Millera współtwórcy metody dialogu motywacyjnego i wybitnego badacza, laureata Jellinek Memorial Awards z 1994 r., profesora psychologii i psychiatrii z University of New Mexico w Albuquerque. Wypowiedział je po 40 latach zajmowania się uzależnieniami: „Nigdy nie zrozumiem alkoholizmu ani istoty AA od środka, ale $\mathrm{z}$ czasem zacząłem $\mathrm{z}$ dużą wdzięcznością doceniać głębię i zakres tego ruchu - wspólnoty, która niczym niezrażona niesie pomoc ludziom udręczonym cierpieniem. W tym sensie zaprzyjaźniłem się z Billem W.” [111: 272].

Od siebie muszę jeszcze dodać, że odczuwam ogromną satysfakcję z tego, że kierując swoich uzależnionych pacjentów do Wspólnoty AA, mogłem jako lekarz pomóc skutecznie wielu chorym i cierpiącym osobom. Wielu z nich, dzięki terapii i później kontynuacji zdrowienia przez program Dwunastu Kroków, stało się osobami zdrowszymi niż przed swoim zachorowaniem, a to w medycynie spotykane jest niezmiernie rzadko.

\section{- WNIOSKI}

Nie ulega wątpliwości, że zarówno lekarze (szczególnie psychiatrzy), jak i psychologowie przyczynili się w znacznym stopniu do powstania i rozwoju Wspólnoty Anonimowych Alkoholików - na świecie i w Polsce. Z licznych badań wynika, że zaowocowało to istotnym wsparciem ze strony Wspólnoty leczenia osób uzależnionych od alkoholu i/lub od innych substancji psychoaktywnych, a także leczenia osób cierpiących z powodu innych problemów zdrowia psychicznego. Udział we Wspólnocie należałoby traktować jako dobrą formę radzenia sobie z zaburzeniami używania alkoholu oraz jako jedną 
disorders and as one of the most promising and effective forms of post-therapeutic care, which favors the consolidation of treatment results and thus not only saves human health and life, but also significantly relieves public health care system. z najbardziej obiecujących i skutecznych form opieki postterapeutycznej, która sprzyja utrwalaniu wyników leczenia i w ten sposób nie tylko ratuje zdrowie i życie ludzkie, lecz także w istotnym stopniu odciąża państwowy system ochrony zdrowia.

\section{Acknowledgements/Podziękowania}

I would like to thank Dr. Jacek Moskalewicz for his very valuable input. This has been of immense value and has allowed me to take the social context into deeper consideration in my research. I would also sincerely like to thank Tadeusz AA for his consultancy on the history of AA and all reviewers for their thorough support thus raising the quality of the article.

Składam serdeczne podziękowania dr. Jackowi Moskalewiczowi za cenne uwagi, które pozwoliły mi szerzej uwzględnić kontekst społeczny poruszonych w tym artykule zagadnień. Bardzo dziękuję też Tadeuszowi AA za konsultacje w sprawach dotyczących historii AA, a Recenzentom za wnikliwość, która pozwoliła na podwyższenie merytorycznej jakości tego artykułu.

\section{Conflict of interest/Konflikt interesów}

None declared./Nie występuje.

\section{Financial support/Finansowanie}

None declared./Nie zadeklarowano.

\section{Ethics/Etyka}

The work described in this article has been carried out in accordance with the Code of Ethics of the World Medical Association (Declaration of Helsinki) on medical research involving human subjects, Uniform Requirements for manuscripts submitted to biomedical journals and the ethical principles defined in the Farmington Consensus of 1997.

Treści przedstawione w pracy są zgodne z zasadami Deklaracji Helsińskiej odnoszącymi się do badań z udziałem ludzi, ujednoliconymi wymaganiami dla czasopism biomedycznych oraz z zasadami etycznymi określonymi w Porozumieniu z Farmington w 1997 roku.

\section{References/Piśmiennictwo}

1. Woronowicz BT. Uzależnienia. Geneza, terapia, powrót do zdrowia. Poznań-Warszawa: Media Rodzina i Parpamedia; 2009.

2. Krasińska I. Prasa abstynencka w Wielkopolsce: „Pismo Centralne dla Sprawy Wstrzemięźliwości w Wielkim Księstwie Poznańskim” (1843-1845). Alkohol Narkom 2014; 27: 255-63.

3. Jasiński J. Ruch Trzeźwościowy w Stanach Zjednoczonych. Korzenie amerykańskiej prohibicji. Alkohol Narkom 2008; 21(1): 65-94.

4. White ChT. Lincoln and Prohibition. New York: Abingdon Press; 1921.

5. Yates R, Malloch MS (eds.). Tackling Addiction: Pathways to Recovery. London: Jessica Kingsley Publisher; 2010.

6. Woronowicz BT. Bez tajemnic o uzależnieniach i ich leczeniu. Warszawa: Instytut Psychiatrii i Neurologii; 2001.

7. Jellinek EM. The disease concept of alcoholism. New Brunswick: Hilhouse Press; 1960.

8. Góra A. William James: czlowiek ponad podziałami. https://www.psychiatria.pl/artykul/ william-james-czlowiek-ponad-podzialami/18270 [Access: 27.05.2020].

9. Walle AH. William James' legacy to Alcoholics Anonymous: an analysis and a critique. J Addict Dis 1992; 11(3): 91-9. 
10. Taylor C. Variety of Religion Today: William James Revisited. Cambridge, MA: Harvard University Press; 2002.

11. Kurtz E. Not-God. A History of Alcoholics Anonymous. Center City, MN: Hazelden; 1979.

12. Kaczmarczyk I. Terapeutyczne oddziaływania Wspólnoty Anonimowych Alkoholików. In: Grzesiuk L, Suszek H (eds.). Psychoterapia Pogranicza. Warszawa: Eneteia; 2012, p. $519-46$.

13. James W. Doświadczenia religijne. Seria Classica Religiologica - polskie wydanie. Kraków: Wyd. NOMOS; 2011.

14. Tiebout HM. Therapeutic Mechanisms of Alcoholics Anonymous. Am J Psychiatry 1944; 100 (4): 468-73. DOI: 10.1176/ajp.100.4.468.

15. Tiebout HM. Psychology and Treatment of Alcoholism. Q J Stud Alcohol 1946; 7: 21427.

16. Tiebout H. The Act of Surrender in the Therapeutic Process, with Special Reference to Alcoholism. Q J Stud Alcohol 1949; 10: 48-58.

17. Tiebout H. Surrender versus Compliance in Therapy, with Special Reference to Alcoholism. Q J Stud Alcohol 1953; 14: 58-68.

18. Anonimowi Alkoholicy wkraczaja w dojrzatość. Krótka historia AA. Warszawa: Fundacja Biuro Służby Krajowej AA w Polsce; 1998.

19. Aleksander J. Anonimowi Alkoholicy. Warszawa: Fundacja Biuro Służby Krajowej AA w Polsce; 1997.

20. White WL, Kurtz E. Twelve Defining Moments in the History of Alcoholics Anonymous. In: Galanter M, Kaskutas LA (eds.). Recent Developments in Alcoholism (vol. 18): Research on Alcoholics Anonymous and Spirituality in Addiction Recovery. New York, NY: Springer-Verlag; 2008, p. 37-57. DOI: 10.1007/978-0-387-77725-2.

21. Anonimowi Alkoholicy: historia o tym, jak tysiące mężczyzn i kobiet zostało uzdrowionych z alkoholizmu. New York: Alcoholics Anonimous World Services; Warszawa: Fundacja Biuro Służby Krajowej AA w Polsce; 1996.

22. American Medical Association, Committee on Alcoholism. Hospitalization of patients with Alcoholism. JAMA 1956; 162: 750.

23. Glatt M. Group Therapy in Alcoholism. Br J Addict 1958; 54(2): 133.

24. American Psychiatric Association. Practice guidelines for the treatment of patients with substance use disorders. In: Practice Guidelines for the Treatment of Psychiatric Disorders Compendium. Washington, DC: American Psychiatric Association; 2000, p. 249-348.

25. Levy LH. Self-Help Groups. In: Rappaport J, Seidman E (eds.). Handbook of Community Psychology. Boston, MA: Springer; 2000, p. 591-613.

26. Moos R, Timko Ch. Outcome Research on 12-Step and Other Self-Help Programs. In: Galanter M, Kleber HO (eds.). Textbook of substance abuse treatment, 4th ed. Washington, DC: American Psychiatric Press; 2008, p. 511-21.

27. Vaillant G. Interview: A Doctor Speaks. AA Grapevine. The International Journal of Alcoholics Anonymous 2001; 57 (12). https://www.divisiononaddiction.org/html/reprints/ vaillant.htm [Access: 07.08.2018].

28. Alcoholics Anonymous, 2014 Membership Survey. New York: Alcoholics Anonymous World Services, Inc; 2014. https://www.aa.org/assets/en_US/p-48_membershipsurvey. pdf [Access: 27.05.2020].

29. Kaczmarczyk I. Wspólnota Anonimowych Alkoholików w Polsce. Warszawa: Eneteia; 2008.

30. Service Material from the General Service Office. Estimated worldwide A.A. individual and group membership. Rev 03/19. https://www.aa.org/assets/en_US/smf-132_en.pdf [Access: 27.05.2020].

31. Romaniuk R. Invisible problems of marginalized populations. In: Kotlarska-Michalska A, Farkas KJ, Romaniuk R (eds.). The Invisible Groups in Poland. Poznań: Wydawnictwo Nauk Społecznych i Humanistycznych, Uniwersytet im. Adama Mickiewicza; 2019, p. 33-48.

32. Makela K, Arminen I, Bloomfield K, Eisenbach-Stangl I, Bergmark KH, Kurube N, et al. Alcoholics Anonymous as a mutual-help movement: A study in eight societies. Madison, WI: University of Wisconsin Press; 1996. 
33. Kaskutas LA, Bond J, Weisner C. The Role of Religion, Spirituality and Alcoholics Anonymous in Sustained Sobriety. Alcohol Treat Q 2003; 21(1): 1-16. DOI: 10.1300/ J020v21n01_01.

34. Zemore SE. A Role for Spiritual Change in the Benefits of 12-Step Involvement. Alcohol: Clin Exp Res 2007; 31(3): 76-9.

35. Walton-Moss B, Ellen M, Ray EM, Woodruff K. Relationship of Spirituality or Religion to Recovery from Substance Abuse. J Addict Nurs 2013; 24(4): 217-26.

36. Montes KS, Tonigann JS. Does Age Moderate the Effect of Spirituality/Religiousness in Accounting for Alcoholics Anonymous Benefit? Alcohol Treat $Q$ 2017; 35(2): 96-112.

37. Vandivier AM. The Growth of Spiritual Awareness through AA Participation: A Phenomenological Study. Alcohol Treat $Q 2020 ; 38(1)$ : 32-49. DOI: 10.1080/07347324. 2019.1586498 .

38. Kelly J. Is Alcoholics Anonymous religious, spiritual, neither? Findings from 25 years of mechanisms of behavior change research. Addiction 2016; 112(6): 929-36.

39. Kurtz E. Duchowy bardziej niż religijny charakter ruchu Anonimowych Alkoholików. Warszawa: Instytut Psychiatrii i Neurologii; 1990.

40. „Przekaż dalej”. Opowieść o Billu Wilsonie i o tym jak posłanie AA ogarnęlo caly świat. Warszawa: Fundacja Biuro Służby Krajowej AA w Polsce; 2004.

41. Connors GJ, Walitzer KS, Tonigan JS. Spiritual change in recovery. In: Galanter M, Kaskutas LA (eds.). Recent Developments in Alcoholism (vol. 18): Research on Alcoholics Anonymous and Spirituality in Addiction Recovery. New York: Springer-Verlag; 2008, p. 209-27. DOI: 10.1007/978-0-387-77725-2.

42. Dermatis H, Galanter M. The Role of Twelve-Step-Related Spirituality in Addiction Recovery. J Relig Health 2016; 55(2): 510-21.

43. Dwanaście Kroków i Dwanaście Tradycji. Warszawa: Fundacja Biuro Służby Krajowej AA w Polsce; 1996.

44. Kirkland K. The influence of William James on the Spirituality of Alcoholics Anonymous. J Humanist Psychol 2018. https://doi.org/10.1177/0022167818782522.

45. Room R, Greenfield T. Alcoholics Anonymous, other 12 step movements, and psychotherapy in the U.S. population 1990. Addiction 1993; 88(4): 555-62.

46. Yalom I, Molyn L. Psychoterapia grupowa. Teoria i praktyka. Kraków: Wydawnictwo Uniwersytetu Jagiellońskiego; 2016.

47. Anderson DJ. The Minnesota experience. In: Golding P (ed.). Alcoholism: A Modern Perspective. Lancaster, England: MTP Press Limited; 1980, p. 3-19.

48. Anderson DJ, McGovern JP, Dupont RL. The Origins of the Minnesota Model of Addiction Treatment - A First Person Account. J Addict Dis 1999; 18(1): 107-114. DOI: 10.1300/J069v18n01_10.

49. Fisher GL, Roget NA. Encyclopedia of Substance Abuse Prevention, Treatment, and Recovery. Reno: University of Nevada; 2009, p. 547-9.

50. McElrath D. The Minnesota Model. J Psychoact Drugs 1997; 29(2): 141-44. DOI: http:// dx.doi.org/10.1080/02791072.1997.10400180.

51. Zajączkowski H. Leczenie alkoholizmu przewlektego. Wskazówki dla lekarzy, psychologów i pracowników poradni przeciwalkoholowych. Warszawa: PZWL; 1950.

52. Tadeusz z grupy AA „Ster”: Historia AA w Polsce. Tom I. Warszawa: Fundacja Biuro Służby Krajowej AA w Polsce; 2012.

53. Kulisiewicz T. Nieść posłanie. Trzeźwymi Bądźcie 1988; 6: 20-2.

54. Woronowicz B. Warszawskie grupy Anonimowych Alkoholików na tle ruchu AA. Problemy Alkoholizmu 1990; 5-6(414): 3-4.

55. Woronowicz B. Alcoholics Anonymous and their contribution to the Program of an Alcoholism Treatment Unit. Warszawa: ICSAA, working paper; 1990.

56. Woronowicz BT. Historia Wspólnoty Anonimowych Alkoholików i terapeutyczne walory Programu Dwunastu Kroków. Post Psychiatr Neurol 1992; 1: 191-8.

57. Tadeusz z grupy AA „Ster”. Historia AA w Polsce. Tom II. Warszawa: Fundacja Biuro Służby Krajowej AA w Polsce; 2019. 
58. Jannasz M. Alcoholics Anonymous Comes to Poland: The Founding of the Polish AA and the American Connection. Eur J Am Stud 2018 [online]; 13-3, Special issue. DOI: https://doi.org/10.4000/ejas.13694.

59. Kujawski R. Poglądy Tadeusza Bilikiewicza na zagadnienia alkoholizmu w Polsce. Alkohol Narkom 2015; 28: 139-44.

60. Woronowicz BT. Uzależnieni i współuzależnieni na turnusach terapeutycznych w Strzyżynie. Alkohol Narkom 1996; 2(23): 219-24.

61. PARPA. Programy Ograniczania Picia. http://www.parpa.pl/index.php/lecznictwo-odwykowe/programy-ograniczania-picia [Access: 27.05.2020].

62. Ambrogne JA. Reduced-risk drinking as a treatment goal: What clinicians need to know. J Subst Abuse Treat 2002; 22(1): 45-53. DOI: https://doi.org/10.1016/S07405472(01)00210-0.

63. American Psychiatric Association. Diagnostic and statistical manual of mental disorders (DSM-5). Washington: APA; 2013.

64. Debata na temat Programu Ograniczania Picia. Stowarzyszenie Terapeutów Uzależnień. 2018. https://terapeuci.info/2018/06/30/debata-na-temat-programu-ograniczania-piciaz-magazynu-terapia-uzaleznienia-i-wspoluzaleznienia/.

65. Hodgins DC, Leigh G, Milne R, Gerrish R. Drinking goal selection in behavioral self -management treatment of chronic alcoholics. Addict Behav 1997; 22(2): 247-55.

66. Cunningham JA, Breslin FC. Only one in three people with alcohol abuse or dependence ever seek treatment. Addict Behav 2004; 29(1): 221-3.

67. Kohn R, Saxena S, Levav I, Saraceno B. The treatment gap in mental health care. Bull World Health Organ 2004; 82(11): 858-66.

68. Kuramoto SJ, Martins SS, Ko JY, Chilcoat HD. Past year treatment status and alcohol abuse symptoms among US adults with alcohol dependence. Addict Behav 2011; 36(6): $648-53$

69. Grant BF. Barriers to alcoholism treatment: reasons for not seeking treatment in a general population sample. $J$ Stud Alcohol 1997; 58(4): 365-71.

70. National Health Service Confederation. Too much of the hard stuff: what alcohol costs the NHS. Briefing 2010; 193. https://www.nhsconfed.org/ /media/Confederation/Files/Publications/Documents/Briefing_193_Alcohol_costs_the_NHS.pdf [Access: 27.05.2020].

71. Schomerus G, Lucht M, Holzinger A, Matschinger, Carta MG, Angermeyer M. The Stigma of Alcohol Dependence Compared with Other Mental Disorders: A Review of Population Studies. Alcohol Alcohol 2011; 46(2): 105-12.

72. van Boekel LC, Brouwers EP, van Weeghel J, Garretsen HF. Stigma among health professionals towards patients with substance use disorders and its consequences for healthcare delivery: systematic review. Drug Alcohol Depend 2013; 131(1-2): 23-35.

73. Hasin DS, Stinson FS, Ogburn E, Grant BF. Prevalence, correlates, disability, and comorbidity of DSM-IV alcohol abuse and dependence in the United States: results from the National Epidemiologic Survey on Alcohol and Related Conditions. Arch Gen Psychiatry 2007; 64(7): 830-42.

74. Kelly JF, Stout RL, Magil M, Tonigan JS. Pagano ME. Mechanisms of Behavior Change in Alcoholics Anonymous: Does AA lead to better alcohol use outcomes by reducing depression symptoms? Addiction 2010; 105(4): 626-36.

75. Kelly JF, Stout RL, Magill M, Tonigan JS. The role of Alcoholics Anonymous in mobilizing adaptive social network changes: A prospective lagged mediational analysis. Drug Alcohol Depend 2011; 114(2-3): 119-26.

76. Kaskutas LA. Alcoholics Anonymous Effectiveness: Faith Meets Science. J Addict Dis 2009; 28(2): 145-57.

77. Gossop M, Harris J, Best D, Man LH, Manning V, Marshall J, et al. Is attendance at Alcoholics Anonymous meetings after inpatient treatment related to improved outcomes? A 6-month follow-up study. Alcohol Alcohol 2003; 38(5): 421-6.

78. Witbrodt J, Kaskutas LA, Bond J, Delucchi K. Does sponsorship improve outcomes above Alcoholics Anonymous attendance? A latent class growth curve analysis. Addiction 2012; 107(2): 301-11. 
79. Humphreys K, Blodgett JC, Wagner TH. Estimating the Efficacy of Alcoholics Anonymous without Self-Selection Bias: An Instrumental Variables Re-Analysis of Randomized Clinical Trials. Alcohol Clin Exp Res 2014; 38(11): 2688-94.

80. O'Sickey AJ, Hanes J, Tonigan JS. The Relationship between Perceived Alcoholics Anonymous Social Group Dynamics and Getting an AA Sponsor. Alcohol Treat $Q$ 2020; 38(1): 21-31. DOI: 10.1080/07347324.2019.1613942.

81. Timko Ch, Moss RH, Finney JW, Lesar MD. Long-Term Outcomes of Alcohol Use Disorders: Comparing Untreated Individuals with Those in Alcoholics Anonymous and Formal Treatment. J Stud Alcohol 2000; 61(4): 529-40.

82. Bodin MC, Romelsjo A. Predictors of abstinence and nonproblem drinking after 12-step treatment in Sweden. J Stud Alcohol 2006; 67(1): 139-46.

83. Tonigan JS, Toscova R, Miller WR. Meta-analysis of the literature on Alcoholics Anonymous: sample and study characteristics moderate findings. J Stud Alcohol 1996; 57(1): 65-72.

84. McKellar J, Ilgen M, Moos BS, Moos R. Predictors of change in alcohol-related self-efficacy over 16 years. $J$ Subst Abuse Treat 2008; 35(2): 148-55.

85. Moos RH, Moos BS. Participation in treatment and Alcoholics Anonymous: a 16-year follow-up of initially untreated individuals. J Clin Psychol 2006: 62(6): 735-50.

86. Walitzer KS, Dermen KH, Barrick Ch. Facilitating involvement in Alcoholics Anonymous during out-patient treatment: a randomized clinical trial. Addiction 2009; 104(3): 391-401. DOI: 10.1111/j.1360-0443.2008.02467.x.

87. White WL. "Chapter 4" in Peer-based Addiction Recovery Support. Philadelphia, PA: Dept of Behavioral Health and Mental Retardation Services, and Great Lakes Addiction Technology Transfer Center; 2009.

88. Slaymaker VJ, Sheehan T. The Impact of AA on Professional Treatment. In: Galanter M, Kaskutas LA (eds.). Recent Developments in Alcoholism (vol. 18): Research on Alcoholics Anonymous and Spirituality in Addiction Recovery. New York: Springer-Verlag; 2008, p. 59-70. DOI: 10.1007/978-0-387-77725-2.

89. Vaillant GE. Positive Emotions and the Success of Alcoholics Anonymous. Alcohol Treat Q 2014; 32(2-3): 214-24. DOI: 10.1080/07347324.2014.907032.

90. Vaillant GE. Alcoholics Anonymous: Cult or Cure. Aust NZ J Psychiat 2005; 39(6): 431-6.

91. NIAAA. 10-th Special Report to the U.S. Congress on Alcohol and Health. NIAAA; 2000.

92. Swift Yasgur B. AA, Other 12-Step Programs Superior to CBT for Alcohol Addiction. Medscape 2020. DOI: https://www.medscape.com/viewarticle/926801 [Access: 27.05.2020].

93. Kelly JF, Humphreys K, Ferri M. Alcoholics Anonymous and other 12-step programs for alcohol use disorder (Review). Cochrane Database of Systematic Reviews 2020; 3. DOI: https://doi.org/10.1002/14651858.CD012880.pub2.

94. New Cochrane Review finds Alcoholics Anonymous and 12-Step Facilitation programs help people to recover from alcohol problems. https://www.cochrane.org/news/new-cochranereview-finds-alcoholics-anonymous-and-12-step-facilitation-programs-help-people [Access: 27.05.2020].

95. Kownacki RJ, Shadish WR. Does Alcoholics Anonymous work: the results from a meta-analysis of controlled experiments. Subst Use Misuse 1999; 34(13): 1897-916. DOI: $10.3109 / 10826089909039431$.

96. Emrick ChD, Beresford TP. Contemporary negative assessments of Alcoholics Anonymous: A response. Alcohol Treat $Q$ 2016; 34(4): 463-71. DOI: 10.1080/07347324.2016.1217713.

97. Cook CCH. The Minnesota Model in the Management of Drug and Alcohol Dependency: miracle, method or myth? Part II. Evidence and Conclusions. Br J Addict 1988; 83: 735-48.

98. Stinchfield R, Owen P. Hazelden's Model of Treatment and Its Outcome. Addict Behav 1998; 23: 669-83. DOI: https://doi.org/10.1016/S0306-4603(98)00015-X.

99. Grønbæk M, Nielsen B. A randomised controlled trial of Minnesota day clinic treatment of alcoholics. Addiction 2007; 102: 381-8.

100. Gallagher C, Radmall Z, O'Gara C, Burke T. Effectiveness of a national “Minnesota Model" based residential treatment programme for alcohol dependence in Ireland: outcomes and predictors of outcome. Ir J Psychol Med 2018; 35(1): 33-41. 
101. Winters K, Stinchfield R, Opland E, Weller Ch, Latimer W. The effectiveness of the Minnesota Model for treating adolescent drug abusers. Addiction (Abingdon, England) 2000; 95: 601-12. DOI: 10.1046/j.1360-0443.2000.9546011.x.

102. Babor TF, Del Boca FK (eds.). International research monographs in the addictions. Treatment matching in alcoholism. New York: Cambridge University Press; 2003.

103. Woronowicz BT, Lenard W. Próba oceny skuteczności leczenia uzależnienia od alkoholu w oparciu o długość abstynencji. Alkohol Narkom 1996; 2(23): 225-32.

104. Woronowicz BT. Wpływ podstawowego programu terapeutycznego na subiektywną ocenę jakości życia pacjentów uzależnionych od alkoholu. In: Błażejowska M, Gałązka R, Godlewska M, Krzymowska-Kordjak B, Skarzyńska-Szczepaniak E, Zawadzka I. (eds.) Sprawozdanie z działalności 2003 r. Warszawa: Instytut Psychiatrii i Neurologii; 2004, p. 71.

105. Mroziak B, Woronowicz B, Wójtowicz S. Zmiany poczucia koherencji i stylu radzenia sobie ze stresem po podstawowym programie psychoterapii osób uzależnionych od alkoholu. Doniesienie wstępne. Alkohol Narkom 1999; 2(35): 225-36.

106. Anthony WA. Recovery from mental illness. The guiding vision of the mental health service system in the 1990s. Psychosocial Rehabilitation Journal 1996; 16(4): 11-23.

107. Akerlind I, Homiquist JO, Elton M, Bjurulf P. Overall functioning and criteria of progress in rehabilitation of alcohol abusers: Longitudinal analyses of changes. Alcohol: Clin Exp Res 1990; 14(6): 856-62.

108. Duckert F. Predictive Factors for Outcome of Treatment for Alcohol Problems. J Subst Abuse 1993; 5: 31-44.

109. Vonnegut K. The Worst Addiction of Them All. An excerpt from the new eBook Vonnegut by the Dozen: Twelve Pieces. The Nation 2013. https://www.thenation.com/ article/archive/worst-addiction-them-all/ [Access: 30.05.2020].

110. Varga K. Zapytajcie Vonneguta, on wie. Listy i biografia słynnego pisarza. Gazeta Wyborcza 25 lutego 2015. https://wyborcza.pl/1,76842,17479312,Zapytajcie_Vonneguta_ on_wie_Listy_i_biografia_slynnego.html [Access: 30.05.2020].

111. Miller WR, Forcehimes AA, Zweben A. Terapia uzależnień. Podręcznik dla profesjonalistów. Kraków: Wydawnictwo Uniwersytetu Jagiellońskiego; 2014. 
